\title{
Nothing SeEmingly Works IN SENTENCING: NoT MANDATORY PENAlties; Not Discretionary Penalties-But Science Has the Answer
}

\author{
MIRKO BAGARIC ${ }^{*}$,GABRIELLE WOLF† ${ }^{\dagger} \&$ DANIEL MCCORD ${ }^{\ddagger}$
}

\section{INTRODUCTION}

Sentencing is undergoing significant reform in the United States. The main catalyst for this shift is the mass incarceration crisis that has developed over the past four decades, ${ }^{1}$ and has resulted in the United States becoming the most punitive nation on Earth, and by an extremely large margin. ${ }^{2}$ The financial cost of imprisoning more than two million Americans, who are disproportionately from African-American and Latino communities, has become unsustainable. ${ }^{3}$ The

* Professor, Dean of Law, Swinburne University, Melbourne.

$\dagger$ Associate Professor, Deakin University, Melbourne.

+ J.D. Candidate 2020, Northwestern University, Pritzker School of Law.

1. It is widely accepted that the United States is experiencing a mass incarceration crisis, see, e.g., Sasha Abramsky, American Furies: Crime, Punishment And Vengeance In The Age Of Mass Imprisonment (2007); Sharon Dolovich, Creating the Permanent Prisoner, in Life Without Parole: America’s New Death Penalty? 96 (Charles J. Ogletree Jr. \& Austin Sarat eds., 2012); Anthony Thompson, Releasing Prisoners, RedeEming Communities: Re-entry, RaCE, ANd Politics (2009); Lynn Adelman, What the Sentencing Commission Ought to Be Doing: Reducing Mass Incarceration, 18 Mich. J. RACE \& L. 295 (2013); Todd R. Clear \& James Austin, Reducing Mass Incarceration: Implications of the Iron Law of Prison Populations, 3 HARV. L. \& Pol'y ReV. 307 (2009); David Cole, Turning the Corner on Mass Incarceration?, 9 OHIо ST. J. CRIM. L. 27 (2011); Bernard E. Harcourt, Keynote: The Crisis and Criminal Justice, 28 GA. ST. U. L. Rev. 965 (2012); Andrew E. Taslitz, The Criminal Republic: Democratic Breakdown as a Cause of Mass Incarceration, 9 OHIO ST. J. CRIM. L. 133 (2011); Anne Traum, Mass Incarceration at Sentencing, 64 Hastings L. J. 423 (2013). The problem is so acute that even a 'Reverse Mass Incarceration Act' has been proposed. Lauren-Brooke Eisen \& Inimai M. Chettiar, The Reverse Mass Incarceration Act, BRENNAN CTR. FOR JUST. (Oct. 12, 2015), https://www.brennancenter.org/ publication/reverse-mass-incarceration-act [https://perma.cc/5KEY-MXTW]; see also the report by the U.S. Justice Action Network, Reforming the NAtion's CRiminal Justice System:The ImPACt of 2015 AND Prospects for 2016 (Dec. 2015). See Part II of this Article.

2. Incarceration, The SEnTEncIng Project, http://www.sentencingproject.org/template/ page.cfm?id=107 [https://perma.cc/NH9V-CVLS]; Nick Wing, Here Are All Of The Nations That Incarcerate More Of Their Population Than The U.S., Huffington Post (Aug. 13, 2013), http://www.huffingtonpost.com/2013/08/13/incarceration-rate-per-capita_n_3745291.html [https://perma.cc/89WJ-CCDV]. Current incarceration rates are historically and comparatively unprecedented. The United States has the highest incarceration rates in the world, reaching extraordinary absolute levels in the most recent two decades. NAT'L RESEARCH COUNCIL, THE Growth of INCARCERATION IN THE United States: EXPLORING CAUSES AND CONSEQUENCES 68 (Jeremy Travis et. al. eds., 2014) [hereinafter NAT'L Research Council, The Growth of INCARCERATION IN THE UNITED STATES].

3. See Part II of this Article. 
human toll of mass incarceration, including the fragmentation of families and communities, is also intolerable. ${ }^{4}$ Moreover, there are no meaningful benefits from mass incarceration; empirical data confirms that increasing the number of prisoners does not make the community safer. ${ }^{5}$

Growing consciousness and acceptance of the failures of mass incarceration have resulted in the United States' Federal Government and some state governments taking steps to attempt to reduce incarceration levels. These efforts have resulted in only a small reduction in prison numbers, ${ }^{6}$ however, because they have been piecemeal and lack an overarching framework. ${ }^{7}$ In order to reduce incarceration levels substantially, it is necessary to implement more wide-ranging reforms.

It is broadly assumed that one of the key reasons for the mass incarceration crisis is the proliferation of mandatory sentencing laws over the past five decades. ${ }^{8}$ Consequently, there is now considerable momentum to abolish many prescriptive sentences. ${ }^{9}$ Yet, in this Article, we contend that this proposal would be ineffective in lowering incarceration numbers significantly and would also not be jurisprudentially sound. This is evident from the example of Australia, which bears many political, social, legal and economic similarities to the United States, but has a very different sentencing methodology. In contrast to the United States, Australia has very few mandatory sentences. ${ }^{10}$ Rather, Australian courts have wide-ranging discretion to impose sentences that accord "individualized justice" in the sense that they are tailored to the particular crime and individual offender. ${ }^{11}$ Notwithstanding the differences between the Australian and United States sentencing systems, Australia is following the United States' trend in increasing incarceration; prison numbers in Australia have tripled in the past three decades. ${ }^{12}$

Thus, the United States' experience demonstrates that mandatory sentences can lead to increased prison numbers. What is less obvious to American lawmakers, jurists, and judges, but is clear from the Australian experience, is that discretionary sentencing can result in the same outcome. It is therefore erroneous to presume that a principled and efficient solution to the mass incarceration crisis would involve shifting from mandatory to discretionary sentencing. In this Article, we highlight the unsatisfactory state of sentencing and criminal justice in Australia, while acknowledging that this is not caused solely by its discretionary sentencing methodology.

We propose that a more effective solution to the mass incarceration crisis would entail the following three key reforms: (i) ensure that the harshness of the

4. $I d$.

5. Id.

6. $I d$.

7. Id.

8. Id.

9. See Part III of this Article.

10. See Part IV of this Article.

11. Id.

12. Id. 
penalties that are imposed are proportionate to the harm caused by the offenses; (ii) implement mechanisms that will accurately predict whether offenders are likely to reoffend; and (iii) draw on technological advances to develop a new sanction that is cheaper and more humane than prison and can more effectively monitor in real time offenders' locations and actions.

In the next part of this Article, we provide an overview of the United States sentencing system and analyze the factors that have led to the mass incarceration crisis. This is necessary in order to contextualize the reform proposals in this Article. This is followed in Part II by an overview of the Australian sentencing system and a discussion of the present growth in incarceration numbers in that country. This discussion provides the backdrop to our argument that abolishing or reducing mandatory sentencing provisions in the United States will, alone, do little to alleviate the incarceration problem. In Part III, we advance our proposed solution to the United States' incarceration crisis. This has three main limbs. As indicated above, the first involves setting penalties at levels that are commensurate with the harm caused by the offenses committed. The second requires the implementation of a methodology to assist courts to accurately determine offenders' likelihood of reoffending. The third proposes developing a new sanction that uses surveillance and sensor technology to monitor the movements and actions of offenders who are not incarcerated. We summarize our reform proposals in the conclusion.

\section{OVERVIEW OF THE UNITED STATES' SENTENCING SYSTEM AND MASS INCARCERATION CRISIS}

\section{A. The United States' Sentencing Framework}

We commence our analysis by providing a brief overview of the sentencing framework in the United States. Sentencing is the process through which courts impose sanctions on criminal offenders. Although the United States federal jurisdiction and each of its states have different sentencing systems, ${ }^{13}$ certain important aspects of those systems, including their objectives, are similar throughout the country. ${ }^{14}$ While these objectives vary in importance, community protection receives the most attention. ${ }^{15}$ This is reflected most prominently in the harsh prescriptive sentencing laws-manifested in fixed, minimum, or

13. Sentencing (and more generally, criminal law) in the United States is mainly the province of the states. See United States v. Morrison, 529 U.S. 598, 613 (2000) (citing United States v. Lopez, 514 U.S. 549, 564 (1995)).

14. The sentencing goals that they share are community protection (also known as incapacitation), general deterrence, specific deterrence, rehabilitation, and retribution. See U.S. Sentencing Comm'n, United States Sentencing Commission Guidelines Manual (2019), http://www.ussc.gov/guidelines/2019-guidelines-manual [hereinafter U.S. SENTENCING COMM'N 2019].

15. Nat'l Research Council, The Growth of InCARCeration in the United States, supra note 2 . 
presumptive penalties ${ }^{16}$ - that now apply at least to some extent in all American jurisdictions. ${ }^{17}$

To understand the operation of prescribed penalty laws and guideline sentencing systems in the United States, it is illuminating to consider the United States Sentencing Commission Guidelines Manual ("Federal Sentencing Guidelines" or "Guidelines"). These guidelines have received the most analysis of all the prescribed penalty systems ${ }^{18}$ greatly influenced state sentencing systems, ${ }^{19}$ and affected many offenders who have been sentenced under them. ${ }^{20}$ Indeed, the federal prison system itself is among the ten largest in the world. ${ }^{21}$

The Federal Sentencing Guidelines resemble most other grid sentencing systems in that penalties are determined principally by two variables: the offender's prior criminal history and the perceived severity of the crime. ${ }^{22}$ In addition to criminal history score and offense severity, the Federal Sentencing Guidelines outline dozens of other considerations that can influence the sanction that is imposed. ${ }^{23}$ Further, judges are permitted to deviate from the Guidelines where there are applicable mitigating and aggravating considerations, which are taken into account mainly in the form of "adjustments" and "departures." ${ }^{24}$ For

16. For the purposes of clarity, these both come under the terminology of fixed or standard penalties in this Article.

17. Nat'l Research Council, The Growth of InCARCeration in the United States, supra note 2, at 325. Twenty of the United States jurisdictions in fact have extensive guideline sentencing systems: Alabama, Kansas, Oregon, Alaska, Maryland, Pennsylvania, Arkansas, Massachusetts, Tennessee, Delaware, Michigan, Utah, District of Columbia, Minnesota, Virginia, Federal (U.S. courts), North Carolina, Washington, Florida, and Ohio. See Richard S. Frase \& Kelly Lyn Mitchell, What Are Sentencing Guidelines?, U. of Minn. Robina Inst. CRIM. L. \& CRIM. Just. (Mar. 21, 2018), http://sentencing.umn.edu/content/what-are-sentencing-guidelines [https://perma. cc/9PAY-R97D].

18. U.S. SENTENCING COMM'N 2019, supra note 14.

19. Ames C. Grawert, Natasha Camhi \& Inimai Chettiar, A Federal Agenda to Reduce Mass Incarceration, BRENNAN CTR. FOR JUST. 1 (2017), https://www.brennancenter.org/sites/default/ files/publications/a\%20federal $\% 20$ agenda $\% 20$ to $\% 20$ reduce $\% 20$ mass $\% 20$ incarceration.pdf [https://perma.cc/GNE6-MYNV].

20. See Douglas A. Berman \& Stephanos Bibas, Making Sentencing Sensible, 4 Оніо ST. J. CRIM. L. 37, 40 (2006). Also, as noted below, the broad structure of the Federal Guidelines is similar to many other guideline systems in that the penalty range is not mandatory and permits departures in certain circumstances.

21. Melissa Hamilton, Sentencing Disparities, 7 Brit. J. AM. Leg. Stud 5 (2017).

22. See Carissa Byrne Hessick, Why Are Only Bad Acts Good Sentencing Factors? 88 B.U. L. REV. 1109 (2008).

23. Amy Baron-Evans, Jennifer Niles Coffin \& Paul Hofer, National Sentencing Resource Counsel, Litigating Mitigating Factors: Departures, Variances, and Alternatives to Incarceration, at i (Nov. 10, 2010), https://static1.squarespace.com/static/551cb031e $4 \mathrm{~b} 00 \mathrm{eb}$ 221747329/t/5883e40717bffc09e3a59ea1/1485038601489/Litigating_Mitigating_Factors.pdf [https://perma.cc/2Q68-3Y8Y].

24. Id. Adjustments are considerations that increase or decrease a penalty by a designated 
example, a demonstration of remorse can result in a decrease of a penalty by up to two levels, and a penalty can be lowered by three levels if it is accompanied by an early guilty plea. ${ }^{25}$ Courts can also invoke considerations that are not set out in the Guidelines to justify departing from the applicable guideline range ${ }^{26}$ if the judges articulate their reasoning for doing so. ${ }^{27}$

Although the Guidelines are only advisory ${ }^{28}$ the guideline range has had a significant impact on many sentencing outcomes. Judges have only recently begun to depart from the Guidelines ${ }^{29}$ but in the past few years there has been a slight increase in the number of sentences imposed within the Guidelines range. Recent data suggests that there has been an incremental increase in sentences handed down within the Guidelines from 47 percent in 2015 to 49 percent in 2016 and $2017,,^{30}$ and 51 percent in $2018 .^{31}$

amount. These are set out in Chapter 3 of the U.S. Sentencing Guidelines. U.S. SEnTEnCING COMM'N 2019, supra note 14. Departures more readily enable courts to impose a sentence outside the applicable guideline range. Id. at 457. See also id. $\S 1 \mathrm{~A} 4(\mathrm{~b})$.

25. Id. at 460 . However, $\S 5 \mathrm{~K} 2.0(\mathrm{~d})(4)$ provides that the court cannot depart from a guideline range as a result of "[t] he defendant's decision, in and of itself, to plead guilty to the offense or to enter a plea agreement with respect to the offense (i.e., a departure may not be based merely on the fact that the defendant decided to plead guilty or to enter into a plea agreement, but a departure may be based on justifiable, non-prohibited reasons as part of a sentence that is recommended, or agreed to, in the plea agreement and accepted by the court. See §6B1.2 (Standards for Acceptance of Plea Agreement)."

26. Id. § 5K2.0(a)(2)(B); see also Gall v. United States, 552 U.S. 38 (2007); Pepper v. United States, 131 S. Ct. 1229, 1247 (2011).

27. U.S. Sentencing Comm'N 2019, supra note 14, §5K2.0(e).

28. United States v. Booker, 543 U.S. 220 (2005). In Booker, the Supreme Court held that aspects of the Guidelines that were mandatory were contrary to the Sixth Amendment right to a jury trial.

29. In 2014, only forty-six percent of sentences imposed by federal courts fell outside the Guidelines, but prior to that, most sentences had fallen within them. Sarah French Russell, Rethinking Recidivist Enhancements: The Role of Prior Drug Convictions, 43 U.C. DAVIS L. REV. 1135, 1160 (2010); see also Amy Baron Evans \& Jennifer Niles Coffin, No More Math Without Subtraction: Deconstructing the Guidelines' Prohibitions and Restrictions on Mitigating Factors, DEFENDER SERVICES OFF. (Nov. 1, 2010), https://www.fd.org/sites/default/files/criminal_defense_ topics/essential_topics/sentencing_resources/deconstructing_the_guidelines/no-more-math-withoutsubtraction.pdf. For a discussion regarding the potential of mitigating factors to have a greater role in federal sentencing see William W. Berry III, Mitigation in Federal Sentencing in the United States, in Mitigation and Aggravation at Sentencing 2471 (Julian V. Roberts ed., 2011). U.S. SEntencing Comm'n, Final Quarterly Data Report, Fiscal Year 2014 (2014), http://www. ussc.gov/sites/default/files/pdf/research-and-publications/federal-sentencing-statistics/quarterlysentencing-updates/USSC-2014_Quarterly_Report_Final.pdf.

30. U.S. Sentencing Comm’n, AnNual Report 2016 (2016), http://www.ussc.gov/about/ annual-report-2016; U.S. SENTENCING COMM’n, ANNUAL REPORT 2017 (2017), http://www.ussc. gov/about/annual-report-2017.

31. U.S. Sentencing COMm'N, Annual Report 2018 (2018), https://www.ussc.gov/ 
The United States Sentencing Commission recently released a report detailing the variations among federal judges across thirty major cities ("Report"). ${ }^{32}$ The Report focuses on three separate periods of time: the period between the decision by the United States Supreme Court in United States v. Booker ("Booker") in 2005, a landmark case that confirmed that it is not mandatory for federal judges to apply the Federal Sentencing Guidelines; the period between Booker and the 2012 United States Sentencing Commission Report; and the period from that report to $2017 .{ }^{33}$ Over all three periods, 413 federal judges from thirty major cities collectively imposed 143,589 sentences. $^{34}$

The Report noted a considerable degree of variation in sentencing, which increased following Booker. It was observed that "[n]ot all of the 30 cities experienced the same changes in differences in sentencing practices since 2005. In some cities, particularly the ones with the largest number of judges, the increases in differences were substantial. ${ }^{" 35}$ The most illuminating finding from the Report was that "[i]n most cities, the length of a defendant's sentence increasingly depends on which judge in the courthouse is assigned to his or her case." "36 Thus, even though the Guidelines prescribe penalty ranges, they are far from rigid and there is ample scope for judges to deviate from them, so much so that the sentiments of the sentencing judge have a major impact in determining any sentence.

The structure of the Guidelines and the application of some departures and adjustments are influenced by the sentencing objectives of community protection, rehabilitation and specific deterrence. Offenders' risk of recidivism is an important consideration in determining the role that these goals play in sentencing. It has been assumed that community protection is best advanced by placing offenders who are at risk of reoffending in prison (or, in rare cases, executing them), and specific deterrence, which involves discouraging offenders from reoffending, can be achieved by imposing harsh sanctions, such as prison. Contrary to specific deterrence, if applied, the goal of rehabilitation, which aims to encourage offenders' internal attitudinal reform by educating them that

about/annual-report-2018.

32. See generally U.S. Sentencing Comm'n, Intra-City Differences in Federal SENTENCING Practices (Jan. 2019), https://www.ussc.gov/sites/default/files/pdf/research-andpublications/research-publications/2019/20190108_Intra-City-Report.pdf [https://perma.cc/Q4Y7RTGT].

33. See generally id.

34. Id. at 12. This sample size includes cities in every region of the nation, as well as eleven of the twelve judicial circuits. Id. The D.C. Circuit was not represented because the "caseload was too small" to meet the threshold for this study (fifty sentences per judge). Id. at 129 n.30. These cases do not include instances where a statutory mandatory minimum exceeded the otherwise applicable guidelines, or when a defendant received a downward departure due to providing substantial assistance to the government. $I d$. at 14. Three other scenarios were excluded due to difficulties in conducting accurate measurements. $I d$. at 15 .

35. Id. at 7 .

36. Id. 
criminal behavior is inappropriate, operates to reduce sentence severity. An offender's low risk of reoffending may indicate that rehabilitation is achievable. ${ }^{37}$ Conversely, offenders who are regarded as being incorrigibly bad are deemed poor candidates for rehabilitation and hence will not receive a penalty reduction on this account.

Thus, an offender's recidivism rating is a crucial variable in the sentencing calculus. One of the key reforms that we propose in this Article, which we discuss further in Part III below, is that the sentencing system use more sophisticated techniques for determining the likelihood that offenders will reoffend. These will produce more accurate results and therefore improve decision-making about how the sentencing objectives can be achieved.

The application of the approach to sentencing described above has resulted in a mass incarceration crisis in the United States. We now discuss the nature and extent of this problem in greater detail.

\section{B. The United States' Incarceration Crisis}

The United States is experiencing a mass incarceration crisis. There are signs that prison numbers are receding, but at an extremely slow rate, and it is clear that a wide-ranging solution is necessary. ${ }^{38}$ The scale of the problem is illustrated by the fact that the United States is the world's largest incarcerator, and by a massive margin.

Currently, approximately 1,517,000 Americans are incarcerated in state and federal prisons and an additional 631,000 prisoners are held in local jails, equating to a total of nearly $2,300,000$ incarcerated people. ${ }^{39}$ Total incarceration numbers peaked at 2,310,300 in 2008. ${ }^{40}$ The number of incarcerated people in the United States per 100,000 adults is 860 , down from 1,000 per 100,000 in 2008 and $2009 .{ }^{41}$ Leading up to 2008 , prison numbers increased nearly four-fold in four decades. ${ }^{42}$ Between 2007 and 2017, ${ }^{43}$ the number of inmates in both prisons and

37. Mirko Bagaric et al., Mitigating America's Mass Incarceration Crisis Without Compromising Community Protection: Expanding the Role of Rehabilitation in Sentencing, 22 LEWIS \& ClaRK L. REV. 1 (2018).

38. See infra Part II.

39. See Wendy Sawyer \& Peter Wagner, Mass Incarceration: The Whole Pie 2020, Prison PoL'y InITIATIVE (Mar. 24, 2020), https://www.prisonpolicy.org/reports/pie2020.html [https://perma.cc/Z2WN-23V7]. Other categories included in the 2,300,000 are: youth $(44,000)$; territorial prisons $(11,000)$; immigration detention $(42,000)$; involuntary commitment $(22,000)$; Indian country (2500); and military (1300). Wendy Sawyer \& Peter Wagner, Mass Incarceration: The Whole Pie 2020, Prison Pol'y InITIATIVE (Mar. 24, 2020), https://www.prisonpolicy.org/ reports/pie2020.html [https://perma.cc/39AE-E2FK].

40. See Danielle Kaeble \& Mary Cowhig, Correctional Populations in the United States, Bureau of Justice Statistics 2 (Apr. 2018), https:/www.bjs.gov/content/pub/pdf/cpus16.pdf [https://perma.cc/USS5-H267] at 2.

41. Id.

42. Albert R. Hunt, A Country of Inmates, N.Y. Times (Nov. 20, 2011), https://www.nytimes. 
jails decreased. The incarceration rate in federal prisons dropped by 3 percent (6,100 individuals) between 2016 and 2017 alone, while the state prison systems saw an overall decline in their incarceration rates of 1 percent $(12,600$ individuals).$^{44}$ Jails have seen significantly larger decreases with a 12-percent drop in incarceration rates between 2007 and $2017 .{ }^{45}$ The rate of incarceration in the private prison system fell 19 percent to a total of 121,400 inmates at the end of $2017 .^{46}$

The reductions in incarceration rates have varied for different social groups. African Americans experienced the highest decline in prison numbers, with a 31percent drop over the decade, and 4 percent of that decrease occurred between 2016 and 2017. ${ }^{47}$ Nevertheless, the gap between the number of African American inmates and other prisoners remains disproportionately wide. At the most extreme end, African American males aged between eighteen and nineteen were twelve times more likely than their white counterparts to be imprisoned in $2017 .{ }^{48}$ There has been a similar trend in jails; despite an overall decrease in the total percentage of the jail population, the rate of incarceration of African Americans is still three times as high as that of white and Hispanic individuals. ${ }^{49}$

Despite the reductions in the number of prisoners, there is still mass incarceration in state and federal prison systems. The federal prison system operated above capacity in 2017, housing nearly 20,000 inmates beyond its rated capacity of approximately 136,000 individuals. ${ }^{50}$ Thirteen states have met or exceeded their maximum capacity, with five of those states-Nebraska (127 percent); Iowa (115 percent); Delaware (110 percent); Colorado (108 percent); and Virginia (102 percent) - operating well above it. ${ }^{51}$ Moreover, changes in incarceration numbers in the various jurisdictions have been inconsistent. It has been noted that:

Thirty-nine states and the federal government had downsized their prisons by 2017. Five states-Alaska, New Jersey, Vermont, Connecticut, and New York - reduced their prison populations by over $30 \%$ since reaching their peak levels. But among the 39 states that reduced levels of imprisonment, 14 states downsized their prisons by less

com/2011/11/21/us/21 iht-letter21.html [https://perma.cc/5Y33-839J].

43. Z. Zeng, Jail Inmates in 2017, BuREAU Just. StAT. 1 (Apr. 2019), https://www.bjs.gov/ content/pub/pdf/ji17.pdf [https://perma.cc/B8SD-DR5P].

44. J. Bronson \& E. Ann Carson, Prisoners in 2017, Bureau Just. Stat. 1 (Apr. 2019), https://www.bjs.gov/content/pub/pdf/p17.pdf [https://perma.cc/ZJ2T-H6BC].

45. See Zeng, supra note 43, at 1.

46. Id.

47. Bronson \& Carson, supra note 44 , at 10.

48. Id. at 15 .

49. Id. at 4 .

50. Id. at 25 .

51. Id. 
than 5\%. Eleven states, led by Arkansas, had their highest ever prison populations in $2017 .^{52}$

As alluded to above, mass incarceration is a relatively new phenomenon in the United States. The rise in prison numbers in the past four decades until their peak in 2008 stemmed from the imposition of more and harsher penalties, which in turn was driven by an increasing crime rate in the 1970s and 1980s during the "War on Drugs," which was declared by President Richard Nixon in the 1960s. ${ }^{53}$ Mark Fondacaro et al. observes that "mass incarceration in America has been fueled by an increased likelihood that an individual will: A) be sent to prison, and B) be assigned to stay for a longer period of time, as prisons have risen as the predominant means of social control." ${ }^{54}$ Michael Tonry notes that harsh prescribed penalties have been a major cause of mass incarceration:

Anyone who works in or has observed the American criminal justice system over time can repeat the litany of tough-on-crime sentencing laws enacted in the 1980s and the first half of the 1990s: mandatory minimum sentence laws (all 50 states), three-strikes laws (26 states), LWOP [life without parole] laws (49 states), and truth-in-sentencing laws (28 states), in some places augmented by equally severe "career criminal," "dangerous offender," and "sexual predator" laws. These laws, because they required sentences of historically unprecedented lengths for broad categories of offenses and offenders, are the primary causes of contemporary levels of imprisonment. ${ }^{55}$

Thus, the key reasons that prison numbers increased were that sentences for many crimes became harsher and these sentences were often mandated by prescriptive laws that did not permit courts discretion to impose more lenient penalties.

This Article proposes reforms that are designed to reduce prison numbers and, in so doing, ameliorate two serious problems stemming from mass incarceration. The first is the exorbitant fiscal cost of this incarceration and the second is the serious damage that incarceration causes to the families of offenders, and the incidental burdens it inflicts on offenders, which often exceed deprivations they suffer as a consequence of the loss of their liberty. Importantly,

52. Nazgol Ghandnoosh, U.S. Prison Population Trends: Massive Buildup and Modest Decline, Sentencing Project (Sept. 17, 2019), https://www.sentencingproject.org/publications/us-prison-population-trends-massive-buildup-and-modest-decline/ [https://perma.cc/94QE-55W2].

53. Nat'L Research Council, The Growth of InCARCERation in the United States, supra note 2, at 119-20.

54. Mark R. Fondacaro et al., The Rebirth of Rehabilitation in Juvenile and Criminal Justice: New Wine in New Bottles, 41 OHio N.U. L. ReV. 697, 707 (2015).

55. Michael Tonry, Remodeling American Sentencing: A Ten-Step Blueprint for Moving Past Mass Incarceration, 13 CRiminology \& PUB. POL'y 503, 514 (2014) [hereinafter Tonry, Remodeling American Sentencing]. For a list of jurisdictions in the United States which use guideline sentencing, see RobINA InST., Sentencing Guidelines Resource Center, U. MinN., http://sentencing.umn.edu/ [https://perma.cc/SCU7-5FFE] (last visited Apr. 26, 2019). 
there are no benefits to the public from mass incarceration that lowering the rate of incarceration will undermine. Mass incarceration does not reduce crime and make the community safer. We now discuss these matters in greater detail.

1. The Unsustainable Financial Burden of Mass Incarceration.-The costs of incarceration in America are, by any measure, exorbitant. ${ }^{56}$ The Prison Policy Initiative calculates that $\$ 182$ billion is spent annually solely on imprisoning offenders. ${ }^{57}$ This sum does not include the social costs stemming from incarceration. Once they are included, it has been estimated that the total cost of incarceration is $\$ 997$ billion annually, which equates to nearly 6 percent of America's Gross Domestic Product. ${ }^{58}$ Due to this substantial expenditure on prisons, significantly less money is available for productive social services, such as education and health. ${ }^{59}$ The National Research Council observes:

Budgetary allocations for corrections have outpaced budget increases for nearly all other key government services (often by wide margins), including education, transportation, and public assistance . . . . Today, state spending on corrections is the third highest category of general fund

56. See further Mirko Bagaric \& Daniel McCord, Decarcerating America: The Opportunistic Overlap Between Theory and (Mainly State) Sentencing Practice as a Pathway to Meaningful Reform, 67 Buffalo L. Rev. 227 (2019).

57. Peter Wagner \& Bernadette Rabuy, Following the Money of Mass Incarceration, PRISON PoL'Y InITIATIVE (Jan. 25, 2017), https://www.prisonpolicy.org/reports/money.html [https:// perma.cc/8ZHY-2V6F].

58. Michael McLaughlin et al., The Economic Burden of Incarceration in the U.S. (Concordance Inst. for Advancing Soc. Justice, Working Paper No. CI072016, July 2016), https://joinnia.com/wp-content/uploads/2017/02/The-Economic-Burden-of-Incarceration-in-the-US2016.pdf [https://perma.cc/N9DF-2M5K].

59. See Michael Mitchell \& Michael Leachman, Ctr. on Budget \& Policy Priorities, Changing Priorities: State Criminal Justice Reforms and Investments in Education (2014), https://www.cbpp.org/research/changing-priorities-state-criminal-justice-reforms-andinvestments-in-education [https://perma.cc/9ZXK-VVN6]; Adam Gopnik, The Caging of America: Why Do We Lock Up So Many People?, New Yorker (Jan. 30, 2012), http://www.newyorker. com/magazine/2012/01/30/the-caging-of-america [https://perma.cc/6XXK-2QYX]. Reduced investment in education is also occurring at the more junior education level: "In recent years . . . states have cut education funding, in some cases by large amounts. At least 30 states are providing less general funding per student this year for K-12 schools than in state fiscal year 2008, before the Great Recession hit, after adjusting for inflation. In 14 states, the reduction exceeds 10 percent. The three states with the deepest funding cuts since the recession hit-Alabama, Arizona, and Oklahoma-are among the ten states with the highest incarceration rates." Mitchell \& Leachman, supra, at 10; see also Beatrice Gitau, The Hidden Costs of Funding Prisons Instead of Schools, CHRistian SCI. Monitor (Oct. 3, 2015), https://www.csmonitor.com/USA/Justice/ 2015/1003/The-hidden-costs-of-funding-prisons-instead-of-schools [https://perma.cc/RKX5LHQY] (noting that eleven states spend more on prisons than universities: Michigan, Oregon, Arizona, Vermont, Colorado, Pennsylvania, New Hampshire, Delaware, Rhode Island, Massachusetts and Connecticut). 
expenditures in most states, ranked behind Medicaid and education. Corrections budgets have skyrocketed at a time when spending for other key social services and government programs has slowed or contracted. ${ }^{60}$

Former President Barack Obama opined that the massive financial cost of incarceration is one that the United States can no longer afford. ${ }^{61}$

Sentiments of this nature have, as discussed below, prompted lawmakers and some members of the community to reflect on the merits of mass incarceration and to governments in some jurisdictions taking concrete measures to reduce prison numbers.

2. The Intolerable Human Toll of Mass Incarceration.-A less noticeable cost of mass incarceration is the burden it imposes on offenders and their relatives. ${ }^{62}$ Given that people from African American ${ }^{63}$ and Latino communities, ${ }^{64}$ and socially and economically disadvantaged white individuals, ${ }^{65}$ are disproportionately represented amongst American prisoners, these social groups suffer the most from the human toll of mass incarceration. Individuals from these groups have a high rate of incarceration for even minor offenses. For example, studies have found that, in California, a disproportionate number of Black and Hispanic people are imprisoned for failing to pay fines for traffic offenses; ${ }^{66}$ in Alameda County, people of color make up 10 percent of the population, but 40 percent of those who are incarcerated in county jails for this crime. ${ }^{67}$ Young people of color are particularly likely to experience the burdens of incarceration. ${ }^{68}$ Research in 2018 exposed that, although young people of color constituted 40 percent of the prison population that had committed crimes against persons, they

60. Nat'L Research Council, The Growth of Incarceration in the United States, supra note 2, at 314 (internal citation and footnote omitted).

61. Barack Obama, The President's Role in Advancing Criminal Justice Reform, 130 HARv. L. REV. 811, 815 (2017).

62. See further Mirko Bagaric et al., A Principled Strategy for Addressing the Incarceration Crisis: Redefining Excessive Imprisonment as a Human Rights Abuse, 38 CARDOZO L. REV. 1663 (2017).

63. Christal Hayes, “This Isn't Just Numbers—But Lives": Half of Americans Have Family Members Who've Been Incarcerated, USA TODAY (Dec. 6, 2018), https://www.usatoday. com/story/news/politics/2018/12/06/half-americans-have-family-who-have-been-jailed-new-studyshows/2206521002/ [https://perma.cc/PS4A-TP4P].

64. Report to the United Nations on Racial Disparities in the U.S. Criminal Justice System, The Sentencing Project 6-7 (2018), https://www.sentencingproject.org/publications/un-reporton-racial-disparities/ [https://perma.cc/RW7R-LT3J].

65. Id.

66. See id. at 12-15.

67. Id. at 15 .

68. See Jeree Michele Thomas \& Mel Wilson, The Color of Youth Transferred to the Adult Criminal Justice System: Policy \& Practice Recommendations, NAT'L Ass'N SOCIAL Workers (2018), http://www.campaignforyouthjustice.org/images/pdf/Social_Justice_Brief_Youth_ Transfers.Revised_copy_09-18-2018.pdf[https://perma.cc/Y6KX-7E9G]. 
comprised 53 percent of those offenders who were moved to adult prisons. ${ }^{69}$ In Florida, for instance, young people of color constitute one-fifth of the young prison population, but 67.7 percent of those who are transferred to adult courts. ${ }^{70}$

The burdens of incarceration are multifarious and extend well beyond the anticipated removal of offenders' liberty. Adam Gopnik has written in The New Yorker about United States prisons" "harshness and inhumanity." incarcerated, offenders are unable to obtain goods and services, ${ }^{72}$ have sexual relationships, ${ }^{73}$ reproduce, or develop their relationships with relatives. ${ }^{74}$ Prisoners in the United States have a higher rate of experiencing physical and sexual abuse than the free population. ${ }^{75}$ Also attributable to their incarceration is prisoners' diminished life expectancy, ${ }^{76}$ limited employment opportunities after release and, ultimately, reduced income. ${ }^{77}$

The families of prisoners also suffer from their incarceration. Research has shown that inmates have a higher rate of divorce than non-prisoners. ${ }^{78}$ More than five million children in the United States have at least one parent who has been incarcerated. ${ }^{79}$ Studies have exposed that the imprisonment of their parents often

69. Id. at 1 . Only eighteen states currently disaggregate their data on transfers by race, so this is not an exhaustive study of the entire nation. See id. at 6.

70. Id. at 9 .

71. Gopnik, supra note 59.

72. Gresham M. Sykes, The Society of Captives: A Study of a Maximum Security PRISON 67-68 (1958).

73. Id. at 70-71; see also RoBert JOHNSON \& HANS Toch, Introduction to THE PAINS OF IMPRISONMENT 13, 13-20 (Robert Johnson \& Hans Toch eds., 1982).

74. Bagaric et al., supra note 62, at 1699-700.

75. Id. at 1702-03. Over 70,000 prisoners are raped in America annually. Id. at 1703 (citing US: Federal Statistics Show Widespread Prison Rape, Hum. Rts. Watch (Dec. 15, 2017), https://www.hrw.org/news/2007/12/15/us-federal-statistics-show-widespread-prison-rape [https://perma.cc/8PJE-U7BU].)

76. A study that examined the 15.5-year survival rate of 23,510 ex-prisoners in the U.S. state of Georgia found much higher mortality rates for ex-prisoners than for the rest of the population. There were 2,650 deaths in total, which was a forty-three percent higher mortality rate than normally expected (799 more ex-prisoners died than expected). The main causes for the increased mortality rates were: homicide, transportation accidents, accidental poisoning (which included drug overdoses) and suicide. Anne C. Spaulding et al., Prisoner Survival Inside and Outside of the Institution: Implications for Health-Care Planning, 173 AM. J. EPIDEMIOLOGY 479, 482 (2011); see also NAT'L Research COUnCIL, The Growth of INCARCERATION IN the United States, supra note 2, at 220-26.

77. Nat'l Research Council, The Growth of InCARCeration in the United States, supra note 2, at 247. One study estimated the earnings reduction to be as high as forty percent. Bruce Western \& Becky Pettit, Incarceration \& Social Inequality, DaEdalus, Summer 2010, at 8,13 .

78. Nat'l Research Council, The Growth of InCARCERAtion in the United States, supra note 2 , at 265.

79. David Murphey \& P. Mae Cooper, Child Trends, Parents Behind Bars: What 
has a detrimental effect on their development and life trajectories. David Murphey and P. Mae Cooper reported that children whose parents are incarcerated frequently also experience other trauma, emotional difficulties and problems in their schooling, largely as a consequence of their parents' minimal involvement in their lives. ${ }^{80}$ Amy Cyphert has explained the nature and causes of these and other effects on children of their parents' incarceration as follows:

Children with an incarcerated parent are more likely to face a range of health issues, from asthma and obesity to depression and anxiety. The data is especially striking for very young children (" $[\mathrm{m}]$ ore than 15 percent of children with parents in federal prison . . . are 4 or younger") and for children whose mothers are incarcerated. For these children, we know that the disruption of parental attachment caused by parental incarceration can sharply increase rates of depression and anxiety and severely disrupt a child's educational performance. Older children do not escape unscathed and still face serious negative impacts when a parent is incarcerated. For example, researchers have concluded that when parents are incarcerated during their children's adolescence, this separation "interrupts key developmental tasks" during the time "when parent-child relations strongly influence issues of identity."

Such effects on children's development can continue to have an impact on them even after their parents are released from prison. Having a parent who has been imprisoned is "a strong risk factor for antisocial behavior, future offending . . . drug abuse, school failure, and unemployment." ${ }^{12}$ In addition, children whose parents have been incarcerated have an increased rate of committing offenses and also being imprisoned. ${ }^{83}$

These many and substantial deleterious effects of incarceration, in addition to the removal of offenders' freedom, on offenders and their families make lowering the prison population even more imperative. Yet the current sentencing system does not take this impact into account.

3. The Absence of Significant Community Benefits From Mass Incarceration. - Given the heavy financial burden of mass incarceration and the suffering that it inflicts on offenders and their families, only a considerable countervailing advantage could justify it, but no such benefit is evident. While it might reasonably be expected that a massive increase in the number of people who are incarcerated would significantly reduce the crime rate, this potential justification for a high rate of imprisonment is unsubstantiated. In fact, many studies have demonstrated that mass incarceration has not meaningfully enhanced

HAPPENS TO THEIR CHILDREN? 1-2 (2015), https:/www.childtrends.org/wp-content/uploads/ 2015/10/2015-42ParentsBehindBars.pdf. [https://perma.cc/4W42-QTJC].

80. Id.

81. Amy B. Cyphert, Prisoners of Fate: The Challenges of Creating Change for Children of Incarcerated Parents, 77 MD. L. REV. 385, 391 (2018) (footnotes omitted).

82. Id. at 392.

83. Id. 
community safety. A recent Brennan Center report notes that "rigorous social science research based on decades of data shows that increased incarceration played an extremely limited role in the crime decline." 84

While, as noted below, there has been a small reduction in incarceration levels in the United States in the past few years, recent studies suggest that this has not coincided with a meaningful increase in the crime rate. In fact, one study indicates that the recent drop in prison numbers has coincided with a reduction in the crime rate. According to data released by the Federal Bureau of Investigation ("FBI"), overall crime rates declined in 2018 in American cities and rural communities of different sizes. ${ }^{85}$ The rates of violent crime and property offenses diminished in communities with different sized populations, but the rates of rape increased in large and mid-sized cities. ${ }^{86}$ There were generally greater declines in the crime rate in mid-sized and small cities than in large cities and rural communities. ${ }^{87}$ In each community, of all the offenses, the rates of robbery diminished the most. ${ }^{88}$ Each region experienced general declines in crime, but the Midwest and South noticeably outpaced the Northeast and West regions of the country in this respect. ${ }^{89}$ In total, each year since 2014 , there have been significant reductions in the crime rate. ${ }^{90}$

Data released by the FBI in late 2019 substantiated these trends and confirmed that they are consistent with longer-term patterns. An article by The Marshall Project sums up the data as follows:

[The] U.S. remains on a decades-long downward trend, falling by 3.9 percent in 2018. Overall, the violent crime rate has plunged by more than 50 percent since the highwater mark of the early 1990s. The drops came across categories of violent offenses, including murder, non-negligent manslaughter and robbery, and property crimes like burglary, larceny and

84. James Austin et al., Brennan Ctr. For Just., How Many Americans Are UNNECESSARILY INCARCERATED 5 (2016), https:/www.brennancenter.org/sites/default/files/ publications/Unnecessarily_Incarcerated_0.pdf [https://perma.cc/LR3G-T737]. For further information, see the studies summarized in Mirko Bagaric, The Punishment Should Fit the Crime-Not the Prior Convictions of the Person That Committed The Crime: An Argument for Less Impact Being Accorded to Previous Convictions in Sentencing, 51 SAN DIEGo L. REV. 343, 384-409 (2014) [hereinafter Bagaric, The Punishment Should Fit the Crime].

85. See U.S .DeP'T Of Just., Preliminary Semiannual Uniform Crime Report, January-June, 2018, Fed. Bureau InVESTigation (June 2018), https://ucr.fbi.gov/crime-in-the-u.s/2018/ preliminary-report/home [https://perma.cc/3J3T-ZRHM]

86. Id. at Table 1, https://ucr.fbi.gov/crime-in-the-u.s/2018/preliminary-report/tables/table-1 [https://perma.cc/G29A-HCY8].

87. $I d$.

88. $I d$.

89. Id. at Table 2, https://ucr.fbi.gov/crime-in-the-u.s/2018/preliminary-report/tables/table-2 [https://perma.cc/98L4-73AV]

90. Id. at Table 3, https://ucr.fbi.gov/crime-in-the-u.s/2018/preliminary-report/tables/table-3 [https://perma.cc/3VSS-VNE7]. 
vehicle thefts, while aggravated assault numbers remained about flat. The rate for rape bucked this trend however, up slightly for 2018, and in each of the last six years. ${ }^{91}$

This analysis is consistent with other research that shows that harsh penalties do not reduce drug crime in particular. A study concerning three states-New York, Michigan and Florida - highlights the failures of mandatory minimum sentences to deter drug-related offending and the lessons that can be learned from this. ${ }^{92}$ Each of these states enacted mandatory minimum sentences for drug crimes in the 1970s in an effort to curb both crime and drug addiction, but failed to do either, while they simultaneously expanded their prison populations. ${ }^{93}$ New York pioneered the first of those laws, and Michigan and Florida followed this example a few years later. ${ }^{94}$ Notably, Michigan passed a mandatory life sentence for any person in possession of more than 650 grams of cocaine or heroin. ${ }^{95}$ Despite compelling evidence of these laws' failure to reduce the crime rate, New York did not change its mandatory minimum sentencing throughout the 1980s and 1990s. ${ }^{96}$ By the late 1990s, that state's murder rate had increased by nearly one-third, and 30 percent of all prisoners were incarcerated for drug crimes. ${ }^{97}$ Michigan did not see better results. ${ }^{98}$ Crime and drug use did not drop, and 86 percent of those convicted under the new mandatory life sentence laws were first-time prisoners and seventy percent of them were poor. ${ }^{99}$ With a 50 -percent spike in crime by 1990 and 35 percent of the prison population comprising drug offenders, Florida's sentencing laws were similarly unsuccessful in lowering the crime rate. ${ }^{100}$

When the states repealed these laws, the crime rates drastically diminished. In New York, despite fearmongering by law enforcement and district attorneys, violent crime and costs associated with prosecuting and incarcerating offenders reduced. ${ }^{101}$ These reforms lowered prison sentences by 40 percent between 2008 and 2014, and the percentage of drug offenders in the prison population fell to 13

91. Jamiles Lartey \& Weihua Li, New FBI Data: Violent Crime Still Falling, MarshaLL ProjeCt (Sept. 30, 2019), https://www.themarshallproject.org/2019/09/30/new-fbi-data-violentcrime-still-falling [https://perma.cc/W7NY-MQ3E].

92. See Greg Newburn \& Sal Nuzzo, Mandatory Minimums, Crime, and Drug Abuse: Lessons Learned, Paths Ahead, JAMES MADISON INST., https://www.jamesmadison.org/wpcontent/uploads/2019/02/PolicyBrief_MandatoryMinimu m s_Feb2019_v04.pdf [https://perma.cc/F7KZ-BXUA] (last visited June 28, 2020).

93. See generally id.

94. See id. at 2.

95. Id.

96. Id. at 2-3.

97. Id. at 3 .

98. See id. at 4.

99. Id.

100. Id. at 5-6.

101. Id. at 4 . 
percent by 2015. ${ }^{102}$ In Michigan, similar reforms have led to significant reductions in crime and associated financial burdens on the state. ${ }^{103}$ Eighty-two percent of the prisoners who were released as a direct result of the elimination of mandatory minimum sentences in 2003 did not reoffend; ${ }^{104}$ the state saved $\$ 15$ million in the succeeding two years, and crime rates have steadily declined in Michigan since that time. ${ }^{105}$

Florida did not follow these other states. ${ }^{106}$ Mandatory minimum sentences for possession of relatively small amounts of certain drugs, such as hydrocodone, remained in place until 2014. ${ }^{107}$ Simultaneously, the use of prescription pain medication, which the mandatory minimum sentences were intended to reduce, has skyrocketed. ${ }^{108}$ By 2012, Florida taxpayers were spending nearly $\$ 100$ million annually to incarcerate drug offenders. ${ }^{109}$ Now that reforms have finally been implemented, taxpayers are estimated to save \$15 million in 2019 and $2020 . .^{110}$

Recent studies have also indicated that harsh mandatory minimum sentencing laws are ineffective in reducing the crimes that they target. Analysis of crack and cocaine use following the passage of the Anti-Drug Abuse Act ("ADAA") and Fair Sentencing Act ("FSA") found that neither statute achieved its intended effect of reducing crack or cocaine use, suggesting that mandatory minimum sentencing is not an effective method of lowering drug usage. ${ }^{111}$ In response to the increase in popularity of cocaine in the 1980s, coupled with the highly publicized crack-related death of a former professional basketball player, Congress passed the ADAA in 1986. ${ }^{112}$ This legislation set substantially harsher penalties for crack and cocaine offenses than for powder cocaine crimes. ${ }^{113}$ Passed in 2010, the FSA reduced mandatory minimum sentences for crack cocaine offenses while maintaining them for powder cocaine crimes, in an effort to combat discrimination in sentencing against people from certain social groups who were more likely to commit crack cocaine crimes. ${ }^{114}$

102. Id. at 3 .

103. Id. at 5 .

104. Id.

105. Id.

106. See id. at 8 .

107. Id.

108. Id.

109. Id.

110. Id.

111. See generally Lauryn Saxe Walker \& Briana Mezuk, Mandatory Minimum Sentencing Policies and Cocaine Use in the U.S., 1985-2013, BMC InTERnATIONAL HeALTH AND Human RIGHTS 1 (2018), https://bmcinthealthhumrights.biomedcentral.com/track/pdf/10.1186/s12914-0180182-2 [https://perma.cc/5PZF-QSNE].

112. Id. at 2 .

113. Id. The penalty for possession of 500 grams of powder cocaine equalled the punishment for possession of just five grams of crack cocaine, or "cocaine base."

114. Id. 
Drawing on a large and diverse sample, the study found that cocaine use declined after the ADAA commenced operation, but cocaine base usage remained largely unchanged. ${ }^{115}$ This indicates a failure on the part of this legislation, which was designed primarily to target cocaine base usage, as it was believed then that cocaine base was more addictive and destructive. ${ }^{116}$ This argument is unsubstantiated by scientific data, however, so there is no evidence that the unchanging rates of cocaine base use reflect its addictive nature, rather than the failure of the ADAA to achieve its intended goal. ${ }^{117}$ While the FSA relaxed restrictions on cocaine base use, it also did not lead to any meaningful change in rates of its use. ${ }^{118}$ This suggests that sentencing law generally does not affect levels of drug usage. ${ }^{119}$ While this study does not rule out other causes for the decline in cocaine use, such as its increased price or decreased supply, it does definitively argue that sentencing policy does not play a role in this shift. ${ }^{120}$

The abovementioned data is, however, at odds with evidence of increasing rates of violent crime, which the Bureau of Justice Statistics ("BJS") reported in September 2019 as follows: ${ }^{121}$

"The longstanding general trend of declining violent crime in the United States, which began in the 1990s, has reversed direction in recent years," based on findings from the National Crime Victimization Survey (NCVS), one of two major sources of crime statistics in the United States. Meanwhile, the long-term decline in property crime has continued in recent years. After declining 62\% from 1994 to 2015 (the most recent year in which a 1-year decline was observed), the number of violentcrime victims increased from 2015 to 2016, and again from 2016 to 2018. Among U.S. residents age 12 or older, the number of violent-crime victims rose from 2.7 million in 2015 to 3.3 million in 2018, an increase of 604,000 victims. This overall rise was driven by increases in the number of victims of rape or sexual assault, aggravated assault, and simple assault. . . . While violent crime rose in recent years, property crime fell, as the portion of households that were victims of property crime fell from $7.99 \%$ in 2014 to $7.27 \%$ in 2018 , while the portion that were victims of burglary dropped from $1.27 \%$ to $1.07 \% .{ }^{122}$

Notwithstanding this data, the weight of evidence indicates that there has

115. See id. at 6.

116. See id. at 7 .

117. See id.

118. See id.

119. See id.

120. See id. at 8 .

121. BJS releases "Criminal Victimization, 2018" reporting increase in violent victimization and decrease in property crime victimization: Rachel E. Morgan \& Barbara A. Oudekerk, Criminal Victimization, 2018, Bureau Just. Stat. (Sept. 2019), https://www.bjs.gov/content/pub/pdf/ cv18.pdf [https://perma.cc/Y29J-77S6].

122. Id. at $1-2$. 
been a reduction in the overall crime rate in recent years. Although this data is not definitive, it is clear that the recent decline in prison numbers has not coincided with a significant increase in crime. In the next part of this Article, we examine more closely the current momentum and changes that have been made to reduce prison numbers in the United States.

\section{Moves to Ameliorate the Mass Incarceration Crisis in the United States Through Sentencing Reform}

1. Support for Sentencing Reform.- - Support for lowering prison numbers has been increasing amongst politicians and the public generally in the United States. ${ }^{123}$ The bipartisan political support for the "tough on crime" agenda of the 1980s and 1990s has shifted, and now representatives and supporters of various political parties have endorsed abolishing the sentencing laws that were passed to pursue that policy by increasing incarceration. ${ }^{124}$ Currently, American voters support a reduction in incarceration two to one regardless of political affiliation. ${ }^{125}$ Sixty-eight percent of Republicans, 78 percent of Independents, and 80 percent of Democrats believe that substantial reforms are urgently required. ${ }^{126}$ Politicians have agitated for the imposition of more lenient sentences for minor offenses and use of sanctions other than incarceration. ${ }^{127}$ Tina Rosenberg observed that this trend is apparent across the political spectrum, noting in a recent article in the New York Times:

Creating mass incarceration 30 years ago was a bipartisan project. So it's fitting that undoing it is as well. One reason for bipartisanship is that the criminal justice system has affected so many people - 30 percent of American adults have a criminal record, which the F.B.I. defines as an arrest on a felony charge. ... On criminal justice reforms, the language from left and right seems to be converging. "Originally, conservatives talked about these issues in terms of public safety, recidivism reduction, curbing government spending and big government," Ms. Harris said. (The prison system is a perfect conservative target: a hugely expensive failure of a government program that deprives people of their freedom.) "And progressives talked in terms of reducing racial disparities and increasing fairness ..."

123. For a further discussion of this section of the Article, see Mirko Bagaric, Gabrielle Wolf \& Daniel McCord, Sentencing Developments in the United States in 2019: Shifting from the "Tough on Crime" Mantra to (Seriously) Contemplating the Abolition of Prisons, 44 CRIM. L. J. (forthcoming 2020).

124. See Alex Busansky \& Eli Lehrer, Voters are Driving Justice Reform, ThE HiLl (Apr. 3, 2019), https://thehill.com/opinion/criminal-justice/437174-voters-are-driving-justice-reform [https://perma.cc/YB6R-9ZD8].

125. See id.

126. See id.

127. See id.

128. Tina Rosenberg, On One Issue, Americans Are United. Too Many Are Behind Bars., N.Y. 
Many of those who are arguing for a reduction in prison numbers have proposed the abolition of mandatory sentences. Even Democratic Party politicians have endorsed this recommendation, though some have argued that this party contributed significantly to the mass incarceration crisis. For instance, Marie Gottschalk commented:

For decades, a growing number of Democrats had been trying to reposition themselves as the party of law enforcement and to lure white voters away from the GOP. . . The \$30 billion law [known as the 1994 Crime Bill], passed 25 years ago this month, was the capstone of their efforts. . . . [I]ts main thrust was a vast array of punitive measures .... . The crime bill did not significantly lower crime rates; it did, however, help transform the United States into the world's warden, incarcerating more of its residents than any other country. ${ }^{129}$

The majority of the candidates from the Democratic Party who are seeking nomination for the next presidential election have promised to reduce the prison population by lowering or eliminating severe mandatory penalties across the country. In her campaign, Senator Kamala Harris stated that she would "end mandatory minimums at the federal level and incentivize states to do the same," 130 while Senator Elizabeth Warren ${ }^{131}$ has proclaimed:

Congress should reduce or eliminate these [mandatory sentencing] provisions, giving judges more flexibility in sentencing decisions, with the goal of reducing incarceration to mid-1990s levels. My administration will also reverse the Sessions memo that requires federal prosecutors to seek the most severe possible penalties, and allow federal prosecutors discretion to raise the charge standards for misdemeanors and seek shorter sentences for felony convictions. ${ }^{132}$

TiMES (Oct. 30, 2019), https://www.nytimes.com/2019/10/30/opinion/on-one-issue-americans-areunited-too-many-are-behind-bars.html [https://perma.cc/5UUG-QYG5].

129. Marie Gottschalk, The Democrats'Shameful Legacy on Crime, New RePublic (Sep. 11, 2019), https://newrepublic.com/article/154631/democrats-shameful-legacy-crime [https://perma.cc/BR63-A348].

130. Douglas A. Berman, Senator Kamala Harris Releases Her Plan "To Fundamentally Transform Our Criminal Justice System," SENT'G L. \& POL'y (Sep. 9, 2019), https://sentencing.typepad.com/sentencing_law_and_policy/2019/09/senator-kamala-harrisreleases-her-plan-to-fundamentally-transform-our-criminal-justice-system.html [https://perma.cc/4AWS-2DQT].

131. Elizabeth Warren, Rethinking Public Safety to Reduce Mass Incarceration and Strengthen Communities, Medium (Aug. 20, 2019), https://medium.com/@teamwarren/rethinking-publicsafety-to-reduce-mass-incarceration-and-strengthen-communities-90e8591 c6255 [https://perma.cc/J9XX-47W7].

132. Douglas A. Berman, Senator Elizabeth Warren Releases Her Plan for "Comprehensive Criminal Justice Reform", SENT'G L. \& POL'Y (Aug. 20, 2019), https://sentencing.typepad.com/ sentencing_law_and_policy/2019/08/senator-elizabeth-warren-releases-her-plan-for- 
Senator Bernie Sanders similarly promised to "stop excessive sentencing with the goal of cutting the incarcerated population in half . . . and . . . [ending] mandatory sentencing minimums." 133 Those campaigning for Joe Biden also asserted that he would "eliminate mandatory minimums ... As president, he will work for the passage of legislation to repeal mandatory minimums at the federal level. And, he will give states incentives to repeal their mandatory minimums."134 Biden vowed to:

Create a new $\$ 20$ billion competitive grant program to spur states to shift from incarceration to prevention .... In order to receive this funding, states will have to eliminate mandatory minimums for non-violent crimes, institute earned credit programs, and take other steps to reduce incarceration rates without impacting public safety. . ${ }^{135}$

Therefore, having identified mandatory sentencing as the predominant reason for the mass incarceration crisis, increasingly more Americans are increasingly arguing for its elimination. We now discuss some of the reforms that have been made at the state and federal levels to lower the harshness of sentencing and prison numbers, which have been significant, but nonetheless piecemeal.

2. Changes to State Sentencing Laws. - Changes that were made to sentencing laws in thirty-four American states from 2007 to 2017 resulted in a lowering of prison numbers, and also of the crime rate. This impact is significant because it reinforces that the imposition of more lenient sanctions does not lead to a more dangerous society. ${ }^{136}$ Notwithstanding this trend, the degree of the shifts in both prison numbers and crime rates, as well as the nature of the reforms that have been made, have differed somewhat between the states. Such variations are unsurprising in light of the general failure to develop consistent reforms that are informed by the same doctrine and policy throughout the country. As a consequence of these variations, the impact of the reforms on crime rates overall is difficult to determine conclusively.

comprehensive-criminal-justice-reform-.html [https://perma.cc/5Z4W-SSTV].

133. Douglas A. Berman, Senator Bernie Sanders Releases Criminal Justice Reform Plan Under Banner "Justice and Safety for All," SENT'G L. \& PoL'y (Aug. 18, 2019), https://sentencing.typepad.com/sentencing_law_and_policy/2019/08/senator-bernie-sandersreleases-criminal-justice-reform-plan-under-banner-justice-and-safety-for-all.html [https://perma.cc/9VPP-BJT2].

134. Douglas A. Berman, Former Veep Joe Biden Releases Extended "Plan for Strengthening America's Commitment to Justice," SENT'G L. \& POL'y (July 23, 2019), https://sentencing. typepad.com/sentencing_law_and_policy/2019/07/former-veep-joe-biden-releases-extended-planfor-strengthening-americas-commitment-to-justice.html [https://perma.cc/P4PP-AYXB].

135. Id.

136. See Cameron Kimble \& Ames Grawert, Between 2007 and 2017, 34 States Reduced Crime and Incarceration in Tandem, BrEnNAN CTR. FOR Just. (Aug. 6, 2019), https://www.brennancenter.org/our-work/analysis-opinion/between-2007-and-2017-34-statesreduced-crime-and-incarceration-tandem [https://perma.cc/8UAF-CVY2]. 
Of all areas of the United States, the Northeast had the highest decline in prison numbers - by $24 \%$ - and, in that area, only Pennsylvania's incarceration rate increased. ${ }^{137}$ Simultaneously, the crime rate dropped by $30 \%$ in this region. ${ }^{138}$ Massachusetts, whose prison population declined by $50 \%$ and whose imprisonment of non-violent drug offenders fell by $45 \%$, experienced the greatest change. ${ }^{139}$ While in many other states, incarceration and crime rates similarly diminished significantly, ${ }^{140}$ prison numbers only reduced by $1 \%$ in the Midwest, and this was attributable to Michigan's reduction of its incarceration levels by $20 \%{ }^{141}$ Michigan invested considerable efforts to achieve this, ${ }^{142}$ largely through introducing reforms that improved offenders' re-entry into society, such as by increasing the rates of parole approval. ${ }^{143}$

Prison numbers also did not diminish and in fact grew in West Virginia, though its crime rate declined. ${ }^{144}$ Notably, in West Virginia and $50 \%$ of the other American states that saw increases in incarceration, there was a particularly high percentage of people living below the poverty line. ${ }^{145}$ In addition, states including West Virginia, Ohio, and Pennsylvania, which all had high prison numbers and severe penalties for drug offenses, experienced an "opioid epidemic" and a large number of people died from drug overdoses. ${ }^{146}$ This data may suggest that increases to the rates of imprisonment and crime are, to some degree, connected to social and economic conditions. ${ }^{147}$

Although some states lowered their prison numbers, they did not always also have reductions in their crime rates. This was the case in Louisiana, which introduced legislative reform that aimed to lower prison numbers over a ten-year period by ten percent in several ways. ${ }^{148}$ First, it reserved prison beds largely for those who were deemed to be dangerous to the community; second, it increased community supervision; third, it removed some of the obstacles to prisoners reentering society; and fourth, it spent money that was previously invested in

137. $I d$.

138. Id.

139. See id.

140. Id.

141. Id.

142. See Dennis Schranz, Stephen DeBor, \& Marc Mauer, Decarceration Strategies: How 5 States Achieved Substantial Prison Population Reductions, Sent'G Project (Sep. 5, 2018), https://www.sentencingproject.org/publications/decarceration-strategies-5-states-achievedsubstantial-prison-population-reductions/ [https://perma.cc/X4JY-GXZT].

143. Id. at 19.

144. Id.

145. Id.

146. Kimble \& Grawert, supra note 136. Ohio's rate was forty-six out of 100,000 people, while Pennsylvania's was forty-four out of 100,000. Kentucky, a nearby state with a similarly high rate of overdose deaths, experienced the same trend and just doubled its penalties for fentanylrelated offenses.

147. See id.

148. Id. 
prisons on measures for reducing offenders' rates of reoffending and supporting victims of crime. ${ }^{149}$ The reason for Louisiana's failure to reduce its crime rate through this legislation is unclear because it resembles reforms made in other American states that have achieved this.

There are differences in the types of measures that have been used in various states to reduce prison numbers. For example, California removed its mandatory five-year enhancement of sentences for each prior serious felony conviction, ${ }^{150}$ while Florida voted to change the law so that sentencing laws that apply retrospectively could be introduced and more lenient sentences could be imposed for some types of offenses. ${ }^{151}$

Inconsistencies in the means used to seek lower incarceration rates across the United States are in part attributable to the fact that the states make their own political decisions and criminal justice laws. In addition, there have not been any moves to make the states' sentencing laws consistent with one another. Notwithstanding this, some patterns in the nature of the reforms that have been made to reduce incarceration rates amongst various states are apparent.

One trend is that several states have made their sentencing laws relating to drug offenses less harsh, ${ }^{152}$ as they have decriminalised certain drugs. ${ }^{153}$ For instance, Massachusetts removed mandatory minimum sentences for minor drug offenses (though it did also create a mandatory minimum three-and-a-half-year sentence for trafficking synthetic opioids). ${ }^{154}$ Yet this reform, too, has not been adopted by all the states and some have increased sentences for drug possession and trafficking, ${ }^{155}$ especially for those who sell drugs that lead to deaths. ${ }^{156}$ Fatalities from use of fentanyl have led to these changes in particular in Tennessee, Rhode Island and Ohio. ${ }^{157}$ Drug dealers in Tennessee can be charged with second-degree murder if their sale of a Schedule I or II substance results in another's death. ${ }^{158}$ Likewise, in Rhode Island, drug dealers who have sold a drug

149. See generally Louisiana's 2017 Criminal Justice Reforms, PEw (Mar. 1, 2018), https://www.pewtrusts.org/-/media/assets/2018/03/pspp_louisianas_2017_criminal_ justice_reforms.pdf [https://perma.cc/ESN6-ZLQJ].

150. Id. at 10 .

151. Nicole D. Porter, Top Trends in State Criminal Justice Reform, 2018, The SEnTEnCING PROJECT 1 (Jan. 2019), https://www.sentencingproject.org/wp-content/uploads/2019/01/TopTrends-in-State-Criminal-Justice-Reform-2018.pdf [https://perma.cc/8LKN-VJVS].

152. See generally Robert Alt, Criminal Justice Reform: A Survey of 2018 State Laws, THE FEDERALIST SOC'Y (July 2019), https://fedsoc-cms-public.s3.amazonaws.com/update/pdf/ yO6G0S36JiuORuLVgnTmDW4a0LHdBqRLIGX2RZBS.pdf [https://perma.cc/XRQ6-LABQ].

153. Id.

154. Id at 9 . In addition to the harsher penalty on trafficking, the state has imposed new sanctions for repeat drunk driving offenses and a new mandatory minimum sentence for assaulting police officers. $I d$.

155. Id. at 8 .

156. Id.

157. Alt, supra note 152 , at 8 .

158. Id. 
that resulted in a fatality can be sentenced to life imprisonment. ${ }^{159}$ Drug traffickers in Ohio can receive eight-year prison terms for trafficking substances that include fentanyl. ${ }^{160}$ Despite these laws, Ohio has made other reforms to reduce prison numbers, such as removing some mandatory minimum sentences, and requiring sentencing courts to take the objective of rehabilitation into account. ${ }^{161}$

Other commonalities between state reforms include the following. Michigan, Mississippi and Oklahoma have all changed their rules surrounding parole, including reducing prison sentences for breach of parole conditions. ${ }^{162}$ Other states have made reforms to lessen the burdens inflicted on offenders as a consequence of their convictions that increase their difficulty in reintegrating into society. Convicted felons in Colorado, New York, Illinois, and Florida (provided that they did not commit murder or sexual offenses) are now permitted to vote, ${ }^{163}$ and those in Pennsylvania and Delaware have had licensing barriers removed for numerous criminal convictions. ${ }^{164}$

In addition, most state sentencing reforms have removed mandatory sentences, lessened sentences for non-violent offenses, and applied reforms retrospectively so that sentences are reduced. This is exemplified by the recent recommendations of the New Jersey Criminal Sentencing and Disposition Commission as follows:

1. Eliminate mandatory minimum sentences for non-violent drug crimes.

2. Eliminate mandatory minimum sentences for non-violent property crimes.

3. Reduce the mandatory minimum sentence for two crimes - second degree robbery and second degree burglary - that previously have been subject to penalties associated with far more serious offenses.

4. Apply Recommendations \#1, \#2 and \#3 retroactively so that current inmates may seek early release. . . ${ }^{165}$

There are nonetheless exceptions to the state reforms that have made sanctions more lenient. In Maryland, for example, penalties for particular offenses are now harsher; more violent crimes attract 10-year mandatory minimum

159. Id.

160. Id. at 8-9.

161. Id. at 9 .

162. Porter, supra note 151 , at 1 .

163. Id. at $1-2$.

164. Id. at 2 .

165. N.J. Criminal Sentencing \& Disposition Comm’n, Annual Report (Nov. 2019), https://www.njleg.state.nj.us/legislativepub/reports/CSDC_2019_Annual_Report1114C2.pdf [https://perma.cc/FB8D-R7SZ]. 
sentences, ${ }^{166}$ and there are more severe sanctions for sexually abusing a minor. ${ }^{167}$

3. Changes to Federal Sentencing Law.-Despite President Donald Trump's "tough on crime" campaign policies, there have also been reforms in the federal jurisdiction designed to reduce the incarceration rate, which have been more extensive and systematic than the changes to state sentencing laws. ${ }^{168}$ Particularly significant are reforms that have enabled the retroactive reduction of non-violent offenders' prison terms in response to the results of the application of tools that assess offenders' risk of recidivism.

The FIRST STEP (an acronym for the Formerly Incarcerated Re-enter Society Transformed Safely Transitioning Every Person) Act, which was introduced in December 2018 with bipartisan political support, has affected the most substantial reforms to lower the federal incarceration rate. ${ }^{169}$ Major changes that it has introduced are as follows. Various offenses, including drug crimes, now attract more lenient sanctions; offenders' criminal history plays a greater role in the determination of their sentences; ${ }^{170}$ and prisoners can be released early. The latter can occur where the Federal Bureau of Prisons agrees to move "low risk" offenders to home detention once they have served the bulk of their sentences, ${ }^{171}$ or prisoners qualify for an "Elderly Home Detention" program on the basis that they are over sixty years of age, have completed two-thirds of their sentences, and have not been convicted of certain serious offenses. ${ }^{172}$

Especially momentous is the requirement specified by this legislation for the

166. Alt, supra note 151 , at 10.

167. Id. at 10-11.

168. Jenna Goff \& Joan Greve, Trump vs Clinton: Criminal Justice Reform, PBS: Wash. WEEK (Sept. 19, 2016), http://www.pbs.org/weta/washingtonweek/blog-post/trump-vs-clintoncriminal-justice-reform [https://perma.cc/6V47-QJSA]; Michelle Mark, Here's What Hillary Clinton and Donald Trump Think about Criminal Justice, Bus. Insider AustL. (Sept. 27, 2016), https://www.businessinsider.com.au/trump-and-clinton-on-issues-mass-incarceration-and-criminaljustice-2016-9?r=US\&IR=T [https://perma.cc/2Y98-A9VH].

169. President Donald J Trump Secures Landmark Legislation to Make Our Federal Justice System Fairer and Our Communities Safer, White House (Dec. 21, 2018), https://www. whitehouse.gov/briefings-statements/president-donald-j-trump-secures-landmark-legislation-tomake-our-federal-justice-system-fairer-and-our-communities-safer/ [https://perma.cc/68QECQDD]; Douglas A. Berman, Prez Trump Signs Historic (Though Modest) FIRST STEP Act into Law . . and Now Comes the Critical Work of Implementing It Well!!, SENT'G L. \& POL'Y (Dec. 21, 2018), https://sentencing.typepad.com/sentencing_law_and_policy/2018/12/prez-trump-signshistoric-though-modest-first-step-act-into-law-and-now-comes-the-critical-work-of-i.html [https://perma.cc/9KB8-S93J].

170. Gina Martinez, The Bipartisan Criminal-Justice Bill Will Affect Thousands of Prisoners. Here's How Their Lives Will Change, TIME (Dec. 20, 2018), http:/time.com/5483066/congresspasses-bipartisan-criminal-justice-reform-effort/ [https://perma.cc/EAE2-Z66P].

171. Brandon Sample, The First Step Act Bill Summary Explained: A Comprehensive Analysis, SENTENCING.NET (Dec. 19, 2018), https://sentencing.net/legislation/the-first-step-act-2018summary [https://perma.cc/KZ82-DYS5].

172. Id. 
Attorney General to create a "Risk and Needs Assessment System", which evaluates prisoners' risk of reoffending and the programs that will assist them most to lower that risk. ${ }^{173}$ The Attorney General is also required to ensure that prisoners can participate in these programs so they can maximise their opportunity of being released early, though offenders who have been convicted of many types of generally violent crimes are not eligible for early release. ${ }^{174}$

Pursuant to this legislation, the Department of Justice ("DOJ") has recently developed the Prisoner Assessment Tool Targeting Estimated Risk and Needs program, which is based on an algorithm and incorporates the following key features. ${ }^{175}$ First, the DOJ aims to introduce dynamic individualized assessment, which evaluates offenders' risks and needs by reference to factors that are susceptible to change, including their conduct while incarcerated, rather than immutable matters such as the nature of their offenses. ${ }^{176}$ Second, the DOJ has proposed that there be periodic re-validation and update of the tool so that it remains effective. ${ }^{177}$ Third, the DOJ will aim to make the tool racially and ethnically neutral, so that particular social groups are not prejudiced as a consequence of its application. ${ }^{178}$ Fourth, the DOJ proposes assessment of offenders' criminogenic needs so that measures can be developed to lessen their risks of reoffending. ${ }^{179}$

The DOJ has promised to implement the FIRST STEP Act fully by January 2020 and has begun work to achieve this. ${ }^{180}$ It has indicated that its implementation of the tool will involve: undertaking a risk and needs assessment of all prisoners; improving the needs assessment system; bringing the earned time credit system into operation; making the workflow automatic; and bringing into effect policies that incite prisoners to participate in programs that can reduce their risk of reoffending and thus maximize their chances of early release. ${ }^{181}$

The United States Sentencing Commission confirmed that, as of July 31, 2019, application of the FIRST STEP Act had resulted in reductions of close to 1,700 sentences for crack cocaine offenders by an average of almost six years. ${ }^{182}$

Other reforms have also been introduced in the federal jurisdiction to provide financial incentives to the states to lower their incarceration rates. This is

173. Id.

174. Id.

175. Office of the Attorney General, The FIRST STEP ACt of 2018: RisK AND NeEdS AsSESSMENT SySTEM 26 (July 19, 2019).

176. Id.

177. Id. at 27-28.

178. Id. at 28 .

179. Id at 29 .

180. Id.

181. See $i d$. at 71-72.

182. U.S. Sentencing Comm'n, First Step Act of 2008 Resentencing Provisions: RETROACTIVITy DATA REPORT (Aug. 2019), https://www.ussc.gov/sites/default/files/pdf/researchand-publications/retroactivity-analyses/first-step-act/20190903-First-Step-Act-Retro.pdf [https://perma.cc/C26R-YY76]. 
exemplified by the Reverse Mass Incarceration Act, a bill reintroduced by Democratic Senators Cory Booker and Richard Blumenthal and Democratic Representative Tony Cardenas. ${ }^{183}$

\section{Overview of Sentencing Reforms Introduced in the United States to Tackle Mass Incarceration}

Thus, relatively wide-ranging reforms have been made to the United States sentencing system in an attempt to curb prison numbers. However, these changes have been piecemeal and have only slightly reduced incarceration rates. At the current pace of decarceration, it is estimated that it will take up to forty years to return to the rate of imprisonment in $1971 .{ }^{184} \mathrm{~A}$ more systematic approach is required in order to address the mass incarceration crisis meaningfully. As we have seen, the most common reform proposed and implemented in the United States to deal with the crisis has been the abolition of mandatory minimum sentences and a move to a discretionary sentencing system. However, this approach is unlikely to lower prison numbers substantially. Mass incarceration can occur just as readily in a system of discretionary sentencing. This is demonstrated by the Australian sentencing system. Before we discuss the reforms that we consider are necessary to ameliorate the mass incarceration crisis in the United States, we analyze the Australian system and, in so doing, debunk the view that abolishing mandatory penalties can greatly help to solve this crisis.

\section{THE SENTENCING AND INCARCERATION CRISIS IN AUSTRALIA: DISCRETIONARY SENTENCING DOES NOT NECESSARILY LEAD TO MORE LENIENT SENTENCING OR LOWER PRISON NUMBERS}

Like all countries, imprisonment rates are lower in Australia than in the United States. The incarceration rate in Australia is 230 prisoners per 100,000 adults. ${ }^{185}$ This is much lower than the imprisonment rate in the United States, but there are at least five notable similarities between sentencing outcomes and objectives in these two countries as follows.

The first is that the Australian prison rate has more than tripled in the past three decades. This is a striking parallel with the situation in the United States, where the prison rate quadrupled in the four decades leading up to 2010. Second, the sentencing objectives in Australia are the same as those in the United States, namely, community protection, general deterrence, specific deterrence, retribution, and rehabilitation. ${ }^{186}$ The third similarity between these countries is

183. Lauren-Brooke Eisen \& Inimai Chettiar, Joe Biden, Cory Booker, the 1994 Crime Bill and the Future: How to Unwind American Mass Incarceration, N.Y. DAILY News (May 21, 2019), https://www.nydailynews.com/opinion/ny-oped-biden-booker-the-crime-bill-and-the-future20190521-gciohe4zlbd2haayddqzns7fn4-story.html [https://perma.cc/C26L-YE6A].

184. Porter, supra note 151. 1971 was the last time the crime rate was as it is today. Id.

185. 4512.0 - Corrective Services, Australia, September Quarter 2019, Austl. BurEAU STAT. (Sept. 2019), https://www.abs.gov.au/ausstats/abs@.nsf/mf/4512.0 [https://perma.cc/F4PG-B7AT].

186. Mirko Bagaric et al., United States Sentencing Developments: The World's Largest Mass 
the amount of money spent on incarceration. While the prison rate in Australia is approximately one-third less than that in the United States, it costs well over $\$ 100,000$ a year to detain each offender. ${ }^{187}$ This is about three times the cost of imprisoning an offender in the United States. Thus, per capita, Australians spend approximately the same amount on incarceration as Americans. The fourth similarity between the sentencing outcomes in these two countries is that their prison populations disproportionately comprise individuals from the most socially and economically disadvantaged communities. In the United States, African Americans are imprisoned at over three times the rate of other Americans. ${ }^{188}$ The situation is even more appalling in Australia, where Indigenous Australians are imprisoned at approximately thirteen times the rate of other Australians. ${ }^{189}$ The fifth similarity between the United States and Australia is that the increases in prison numbers have been attributable not to increasing crime rates, but rather to harsher penalties. ${ }^{190}$

Thus, Australia and the United States share the same problems in sentencing outcomes. Nevertheless, there is one important difference between the sentencing systems of these two countries: mandatory or prescriptive sentences are very rare in Australia. ${ }^{191}$ Instead, courts in Australia can impose the sentence that seems appropriate in light of the nature and circumstances of the offense. The only strict limit on courts' discretion to impose the sentence they regard as appropriate is that they cannot impose a penalty that exceeds the maximum penalty prescribed for the offense. The methodology that Australian courts are required to follow is termed the "instinctive synthesis." This term was coined by Justices Adam and Crockett of the Full Court of the Supreme Court of Victoria in the case of $R v$ Williscroft where they stated: "Now, ultimately every sentence imposed represents the sentencing judge's instinctive synthesis of all the various aspects involved in the punitive process." 192

As these judges suggest, in undertaking the instinctive synthesis to reach a specific sanction, judges need to make decisions regarding each of the factors that are relevant to sentencing, attach a particular weight to them, and balance them against one another. Nevertheless, in so doing, judges are prohibited from stipulating the precise mathematical weight that they have attached to any of the factors that have influenced their decisions. ${ }^{193}$ In Wong $v$ The Queen, a majority

Incarcerator Goes into Decarceration Mode, 43 CRIM. L.J. 130 (2019).

187. Id.

188. Id.

189. Id.

190. Mirko Bagaric \& Athula Pathinayake, Jail Up; Crime Down Does Not Justify Australia Becoming an Incarceration Nation, 40 AustrL. B. REV. 64, 64-88 (2015).

191. Mirko Bagaric, An Argument for Uniform Australian Sentencing Law, 37 AUSTRL. B. REV. 40 (2013).

192. R v Williscroft, (1975) VR 292, 300 (Austl.).

193. The only exceptions are the discounts for pleading guilty and cooperating with authorities. See Mirko Bagaric, Abolishing the Curious Sentencing Anomaly Between the Voluntary Disclosure of One's Own Offending and Assisting Authorities with the Offending of Others, 43 
of the High Court of Australia justified the application of the instinctive synthesis on the basis that the sentencing process is extremely complex, multifaceted, and imprecise. ${ }^{194}$

The nebulous nature of the instinctive synthesis has been criticized for diminishing the predictability, transparency, and consistency of sentencing law. ${ }^{195}$ Application of the instinctive synthesis compromises predictability and transparency in sentencing decision-making because it does not enable judges to articulate the steps that they have taken to reach a sentence. Moreover, there is emerging evidence that the instinctive synthesis leads to considerable inconsistency in the outcomes of cases and to adverse outcomes, including heavier penalties for certain offender cohorts, such as Aboriginal offenders, perhaps as a result of judges' unconscious bias. ${ }^{196}$ Despite these criticisms, the instinctive synthesis remains the methodology for making sentencing decisions in Australia.

Most importantly for the purposes of this Article, the discretionary approach to sentencing in Australia is diametrically opposite to the nature of sentencing decision-making in the United States. Yet Australia, too, is experiencing an incarceration crisis brought about by the imposition of excessively punitive sanctions. This demonstrates that abolishing or reducing mandatory penalties will not improve sentencing outcomes in the United States. There is nonetheless a solution to the sentencing failures in the United States. It has three components, which we now examine.

\section{PROPOSALS FoR SENTENCING REFORM IN THE UNITED STATES}

\section{A. Imposing Proportionate Penalties}

The first component of our proposed solution to the United States' mass incarceration crisis is to cease punishing offenders gratuitously and excessively

Monash U. L. ReV. 299, 299-330 (2017).

194. Wong v the Queen (2001) 207 CLR 584, 94 [74]-[78] (Gaudron, Gummow and Hayne JJ) (Austl.). See also the dicta of McHugh J., who noted the difficulties of any "attempts to give the process of sentencing a degree of exactness which the subject matter can rarely bear." AB v The Queen (1999) 198 CLR 111 (Austl.).

195. See, e.g., Austin Lovegrove, An Empirical Study of Sentencing Disparity Among Judges in an Australian Criminal Court, 33 InT'L ReV. ApPLIEd PsYChOl. 161 (1984); T. Vinson ET AL., Criminology Research Council, Accountability and the Legal System: Drug Cases Terminating In the District Court 1980-1982, (1986); Samantha Jeffries \& Christine Bond, Does Indigeneity Matter? Sentencing Indigenous Offenders in South Australia's Higher Courts, 42 Australian \& N.Z. J. CRIMinology 47, 49 (2009). For observations regarding the difficulty in firmly proving inconsistency in sentencing, see Sarah Krasnostein \& Arie Freiberg, Pursuing Consistency in an Individualistic Sentencing Framework: If You Know Where You're Going, How Do You Know When You've Got There?, 76 L. \& Contemp. Probs. 265, 272-73 (2013).

196. Sentencing Advisory Council (Vict.), Comparing Sentencing Outcomes for Koori and Non-Koori Adult Offenders in the Magistrates' Court of Victoria (2013). 
for their crimes. This change requires adoption and implementation of the principle of proportionality, which in its most basic and persuasive form entails that the harshness of the penalty match the seriousness of the crime. ${ }^{197}$

The United States has already embraced the principle of proportionality. ${ }^{198}$ Indeed, it even had some impact on the Guidelines. ${ }^{199}$ Nevertheless, it has been criticized for the reason that the difficulty of matching the severity of a penalty with the gravity of an offense makes it an inherently vague concept. As Jesper Ryberg comments, proportionality "presupposes something which is not there, namely, some objective measure of appropriateness between crime and punishment." ${ }^{200}$ As a consequence of this, it is extremely hard for courts to make proportionate sentencing decisions in cases that they frequently confront. How does a court determine the sanction that is equivalent in severity to the impact of the crime on its victim? Applying the principle of proportionality without any other guidance, judges could reach very different sentencing decisions. Some may argue that proportionality is a means of rationalizing judges' intuition, rather than a meaningful principle that they have carefully applied.

Notwithstanding these problems, it is possible to develop processes that would remove the vagueness associated with the principle of proportionality and enable its application in a practical and uniform way. This involves creating measures for calculating the two limbs of proportionately, namely, the gravity of the crime and the severity of the penalty, and then ensuring that they are equal to one another. The means that we propose for doing so is assessing the well-being of both the victim and the offender, and imposing a sanction that, by virtue of its form and extent of punishment, encroaches on the offender's well-being to the same degree as his or her crime diminished his or her victim's well-being. ${ }^{201}$

197. See Richard G. Fox, The Meaning of Proportionality in Sentencing, 19 MELB. U. L. REv. 489, 491-92 (1993-1994). For a more extensive discussion regarding the proportionality principle, see Mirko Bagaric \& Sandeep Gopalan, Sound Principles, Undesirable Outcomes: Justice Scalia's Paradoxical Eighth Amendment Jurisprudence, 50 AKRon L. REV. 301 (2016).

198. Ten states already require it in their sentencing regimes. E. Thomas Sullivan \& Richard S. Frase, Proportionality Principles in American LaW: Controlling Excessive Government ACtions 154 (2008); see also Gregory S. Schneider, Sentencing Proportionality in the States, 54 ARIZ. L. REV. 241 (2012) (focusing on the operation of the principle in Illinois, Oregon, Washington and West Virginia). At least nine states prohibit excessive penalties in their constitutions. SulLIVAN \& FRASE, supra, at 154-55. Most commonly, twenty-two states prohibit cruel and unusual penalties, including eight states that mandate proportional penalties. Id. at 154 .

199. See U.S. Sentencing Comm'n, U.S. Sentencing Guidelines Manual ch. 1, pt. A, Policy Statement (2018).

200. Jesper Ryberg, The Ethics of Proportionate Punishment: A Critical INVESTIGATION 184 (2004).

201. See Mirko Bagaric, Injecting Content into the Mirage That is Proportionality in Sentencing, 25 N.Z. U. L. REV. 411 (2013). The approach has some similarity with the majority opinion of Justice Powell in Solem v. Helm, who stated that the seriousness of the offense is 
Although evaluating any individual's well-being is necessarily an estimate, the notion of well-being has increasingly been used to assess people's progress, either together with or instead of traditional, solely economic measures. For instance, the "Better Life Index," created by the Organization for Economic Cooperation and Development, outlines and ranks matters that are critical for people's "well-being," to inform countries' social and economic goals. ${ }^{202}$ According to this index, the critical components of individuals' well-being relate to their rights to life, physical integrity, liberty, and property. ${ }^{203}$ We propose that crimes that impinge on their victims' sense of safety, health and/or ability to live freely and autonomously should be deemed more serious than offenses that diminish their wealth, such as property offenses. This is because an individual's wealth generally influences their well-being to a lesser degree than these other matters. Moreover, research has shown that violent and sexual offenses affect their victims' well-being to a greater extent than property crimes. ${ }^{204}$ One study

determined by the harm caused and the defendant's degree of culpability. 463 U.S. 277, 293-94 (1983). However, lacking in this analysis is the criteria by which harm is to be determined. This approach is in keeping with the approach of some other theorists. Von Hirsch asserts that an interest's analysis, similar to the living standard analysis he adopts for gauging crime seriousness, should be used to estimate the severity of penalties. Andrew Von Hirsch \& Nils Jareborg, Gauging Criminal Harm: A Living-Standard Analysis, 11 Oxford J. Legal Stud. 1, 34-35 (1991). Ashworth states that proportionality at the outer limits "excludes punishments which impose far greater hardships on the offender than does the crime on victims and society in general." Andrew Ashworth, Sentencing And CRiminal Justice 97 (2d ed. 1995).

202. Create Your Better Life Index, OECD BeTter LIFE InDEX, http://www. oecdbetterlifeindex.org/\#/11111111111 [https://perma.cc/9J6T-UGVB] (last visited Jan. 9, 2017). These measures are designed to be more informative than economic statistics, especially in the form of Gross Domestic Product (GDP). The index lists eleven criteria for measuring life quality. Id. From most to least important is: life satisfaction, health, education, work-life balance, environment, jobs, safety, housing, community, income, and civic engagement. Mirko Bagaric, Proportionality in Sentencing: The Need to Factor in Community Experience, Not Public Opinion, PopulaR Punishment: on the Normative Significance of Public Opinion 76, 90 (Jesper Ryberg \& Julian V. Roberts eds., 2014).

203. This is the trend of information emerging from the following works and extensive research data in these works. See, e.g., Tim Kasser, The High Price Of Materialism (2002); David G. Myers, The Pursuit of Happiness (1992); Martin E. P. Seligman, Authentic Happiness (2002); Michael ARgYle ET AL., Happiness as a Function of Personality and Social Encounters, in Recent Advances in Social Psychology: An International Perspective 189 (Joseph P. Forgas \& J. Michael Innes eds., 1989); Martin E. P. Seligman \& Mihaly Csikszentmilhalyi, Positive Psychology: An Introduction, 55 Aм. Psychologist 5 (2000). The results of these studies are summarized in Mirko Bagaric \& James McConvill, Goodbye Justice, Hello Happiness: Welcoming Positive Psychology to the Law, 10 DeAKIN L. Rev. 1 (2005). For related readings, see this same edition of the Deakin Law Review, which is a thematic edition regarding the link between law and happiness research.

204. Rochelle F. Hanson et al., The Impact of Crime Victimization on Quality of Life, $23 \mathrm{~J}$. 
found that victims, particularly of sexual offenses experienced greater difficulty in forming intimate relationships, ${ }^{205}$ and higher rates of divorce ${ }^{206}$ and unemployment than victims of property offenses. ${ }^{207}$

It is easier to evaluate the extent to which a sanction will set back an offender's well-being. With the exception of capital punishment, a prison sentence is obviously the most severe penalty because, of all the sanctions, it generally has the greatest deleterious effect on an offender's well-being. ${ }^{208}$ As discussed above, in addition to the deprivation of an offender's liberty, incarceration imposes many incidental burdens on an offender. ${ }^{209}$

Given that the above approach assesses both the hardship of punishment and the gravity of crime on the same scale, these variables can be at least crudely matched. To this end, there are several key premises that can underpin the framework for the implementation of the proportionality principle. The first is (as we have examined above) that the crimes that have the most serious adverse consequences for their victims are violent and sexual offenses. Second, the sanction that imposes the most severe hardship on offenders (except for the death penalty) is imprisonment. In light of these considerations, a logical starting point is that imprisonment should generally be imposed only for serious sexual and violent offenses. ${ }^{210}$ Of course, this says nothing about the appropriate length of

Traumatic Stress 189 (2010).

205. Id. at 190-91.

206. Id. at 191.

207. Id. See also Adriaan J.M. Denkers \& Frans Willem Winkel, Crime Victims' Well-Being and Fear in a Prospective and Longitudinal Study, 5 INT'L REV. VictiMOLOGY 141, 155-56 (1998).

208. RYBERG, supra note 200, at 102-03.

209. See Part II.B above.

210. We suggest that most offenses should be dealt with in a manner which does not involve a term of imprisonment and that imprisonment should be mainly reserved for serious sexual and violent offenses. For an argument that penalties need to be also reduced for violent and sexual offenders, see generally Nazgol Ghandnoosh, The Next Step: Ending Excessive Punishment for Violent Crimes, Sentencing Project (Apr. 2, 2019), https://www.sentencingproject.org/ publications/the-next-step-ending-excessive-punishment-for-violent-crimes/. While the mainstream conversation on criminal justice has recently emphasized reductions in drug and other non-violent offenses, there are credible arguments that lowering excessive sentences for violent offenses is critical to ending mass incarceration. While the rates of violent crime have stopped increasing after a spike in the 1990s, half of the current prison population is serving time for violent crimes. This number has remained relatively stagnant since 2009 , while the prison population serving time for drug offenses has declined by one-fifth since then. For that reason, there are several ways in which reducing sentences for violent crimes can make a significant dent in the nationwide prison population. Death and torture, as Ghandnoosh puts it, are currently two pervasive elements of the system that contribute to mass incarceration. As life-without-parole becomes a popular alternative to the death penalty, the number of people serving such sentences has increased four-fold to a high of 50,000 in 2016. On the torture side, Colorado has been a leader in limiting solitary confinement and the harmful effects that make it more difficult for offenders to get out and stay out of prison. 
imprisonment for certain categories of sexual and violent offenses. However, it follows from the above discussion that prison terms for most of these offenses should be reduced from their current duration given that current sentencing practices do not pay sufficient regard to all of the burdens inflicted by imprisonment. ${ }^{211}$

The recommendation to reduce the severity of penalties is in keeping with reforms suggested recently by a number of experts. The basis for these recommendations stems not from the principle of proportionality, but from the

By restricting solitary confinement to no more than fifteen days, and only in the most extreme circumstances, Colorado hopes to end what is effectively torture, to help prisoners avoid the debilitating mental health effects that make it extremely difficult to successfully rehabilitate. Mississippi also passed a meaningful reform by reducing its truth-in-sentencing laws, which require a person to serve a certain portion of their sentence no matter what, from 85 to 50 percent of the total sentence. Since that reform went into effect, Missouri, Oklahoma, and South Carolina have all enacted legislation to create similar reductions in their own truth-in-sentencing laws. Some states have reduced the prison population and violent sentences through gubernatorial powers. Former California Governor Jerry Brown commuted 284 sentences in his final year in office, many of which were lengthy terms of imprisonment for violent offenses. In addition to his actions, he also exercised restraint by reversing parole decisions only $12 \%$ of the time in 2018 , a marked downturn from the average of 54\% among his predecessors from 1991-2010. Governors from both sides of the aisle have shown similar compassion, such as Mike Huckabee of Arkansas through the 1058 pardons and commutations he granted during his eight years in office. John Hinckenlooper of Colorado used his power to grant 18 commutations, including 12 for individuals convicted of murder as teens. In Maryland, despite Governor Larry Hogan's staunch opposition to allowing life sentences to result in parole, a group of 188 elderly "lifers" have gained their freedom through litigation. Important limitations have also been placed on life sentences for juveniles. The Supreme Court acted most recently in 2012 to prohibit mandatory life sentences from being levied against juveniles. Since the ruling in Miller v. Alabama, 567 U.S. 460 (2012), sixteen additional states have banned life-without-parole sentences for juveniles, bringing the total to twenty-one states. New state laws have also specified how courts and parole boards should consider a person's youth. In addition to those reforms, many states have taken action to prohibit or at least restrict sending juveniles to adult courts and prisons as an automatic result of their sentences. This is vital for the well-being of the individual, as it is well-documented that adult incarceration can cause permanent damage to juveniles, and to the disparity of sentencing between racial groups. Limiting the scope of certain statutes has also gone towards limiting sentencing, especially for violent crimes. The Armed Career Criminal Act (ACCA) included vague provisions that allowed 15-year enhancements for gun convictions imposed on individuals with any "violent felonies" or "serious drug offenses" in their history. The Supreme Court struck it down for being overly vague, then applied it retroactively in a later case in 2016. It is estimated that the number of convictions under ACCA has since dropped from 582 to 304 . California took similar action on its felony murder rule, which imposed the harshest penalties for anybody involved in a crime that resulted in a homicide. By limiting who could be charged for the murder, California has made 400-800 individuals eligible for resentencing.

211. See BAgAriC ET AL., supra note 39. 
sentencing objectives of general deterrence and community safety. To this end, it has been suggested that all life sentences should be abolished. ${ }^{212}$ A key reason for this recommendation is that research indicates that life sentences do not deter crime or enhance public safety to any greater extent than twenty-year prison sentences. ${ }^{213}$ Currently, about 200,000 people are serving life sentences in state and federal prisons, which has led to an increase in the average age of prisoners. ${ }^{214}$ As offenses are predominantly committed by young men, the high number of life sentences has not meaningfully lowered the crime rate. ${ }^{215}$ For this reason, German Lopez has suggested that all prison sentences should be capped at twenty-year terms on the basis that this would reduce prison populations without compromising public safety. ${ }^{216}$ Given that people's criminal tendencies tend to wane as they age, life sentences do not reduce offenders' likelihood of reoffending any more than twenty-year prison terms. ${ }^{217}$ Of course, there would need to be some limited exceptions to this rule for offenders such as serial killers, but Lopez suggests that such cases could be managed by allowing courts to extend sentences indefinitely by up to five years if the individual is considered to pose a risk to public safety at the end of their first twenty-year prison term. ${ }^{218}$

While this reform alone would not end mass incarceration, it would meaningfully reduce prison numbers. Just over half of the inmates of state prisons are serving time for violent offenses, which are much more likely to result in prison sentences that are longer than twenty years. ${ }^{219}$ Moreover, the United States currently houses 40 percent of all people in the world who are serving life sentences. ${ }^{220}$ Following the example of European nations, which mostly have shorter sentences while still keeping their crime rates below that of the United States, a cap of twenty years on the length of each prison term could have a

212. See Daniel S. Nagin, Reduce Prison Populations by Reducing Life Sentences, WasH. Post (Mar. 21, 2019), https://www.washingtonpost.com/crime-law/2019/03/21/guest-post-reduceprison-populations-by-reducing-life-sentences/ [https://perma.cc/R4NG-XNHT]. See also Eileen Rivers, The Graying of America's Prisons: 'When is Enough Enough?,'USA TODAY (Sep. 8, 2019, 11:19 AM EDT), https:/www.usatoday.com/in-depth/opinion/lifers/2019/09/03/lifers-aginginmates-federal-prisons-drug-charges/1861873001/ [https://perma.cc/MQ3C-M39M].

213. Id.

214. See id.

215. See id. The percentage of prisoners above the age of fifty has increased from five to twenty percent since 1993. Moreover, the percentage of prisoners above forty years old has doubled from 17.9 percent to forty percent over that same time period.

216. See German Lopez, The Case for Capping All Prison Sentences at 20 years, Vox (Feb. 12, 2019, 7:30 AM EDT), https://www.vox.com/future-perfect/2019/2/12/18184070/maximumprison-sentence-cap-mass-incarceration [https://perma.cc/2XCD-HFSJ].

217. Id.

218. Id.

219. Id.

220. Id. 
meaningful impact on mass incarceration, which other reforms have failed to achieve. $^{221}$

The American Law Institute has made a similar recommendation, suggesting that all sentences be reviewed after an offender has served fifteen years in prison. Further, a bill introduced by Senator Cory Booker and Democratic Party Representative Karen Bass proposes that there should be a sentence review for any offender who has served more than ten years in prison or who is over fifty years old. Their recommendation that this should apply irrespective of the crime that the offender committed is considered "critical, because to combat mass incarceration, to echo the Prison Policy Initiative, reform" needs to address more types of crimes than non-violent drug offenses. ${ }^{222}$

Thus, there is considerable momentum to reduce the length of prison terms. We agree with this approach to tackling the mass incarceration crisis and, in particular, with the reasoning for it. Excessively long prison terms do not facilitate achievement of the aims of general deterrence and community protection any more than shorter prison terms. Like the proportionality principle, this rationale justifies reserving incarceration generally only for offenders who have committed sexual and violent crimes, and typically imposing shorter sentences even for those offenses than is currently the case. The one exception we recommend making to the proposal to reduce penalties substantially for most offenses is that sentences should remain reasonably harsh if there is a significant risk that offenders will reoffend and cause serious harm to other people when they are released from prison. Community protection trumps the principle of proportionality, ${ }^{223}$ and hence it is desirable to incarcerate offenders who have a high risk of recidivism for longer periods. In order to accommodate this approach, it is essential to be able to identify those offenders who are likely to reoffend. In the next section, we discuss our recommendation for the application of a systematic and accurate approach to evaluating this risk.

Prior to considering how the sentencing system can be improved to identify potential recidivists, it is important to consider the optimal manner for setting sanctions that are proportionate to the seriousness of offenses. We argue that this can best be achieved by setting presumptive penalties for all offense categories, using a grid system similar to the one that currently applies in the federal jurisdiction. ${ }^{224}$ It has been observed that, contrary to popular assumption,

221. Id.

222. Ben Miller \& Daniel S. Harawa, Why America Needs to Break Its Addiction to Long Prison Sentences, Politico (Sep. 3, 2019), https://www.politico.com/magazine/story/2019/09/03/ why-america-needs-to-break-its-addiction-to-1ong-prison-sentences-22 7999 [https://perma.cc/ND7R-DA8L].

223. See Mirko Bagaric \& Sandeep Gopalan, Saving the United States from Lurching to Another Sentencing Crisis: Taking Proportionality Seriously and Implementing Fair Fixed Penalties, 60 ST. Louis U. L.J. 169, 169-242 (2016).

224. Id. 
prescriptive guidelines are effective at tailoring appropriate penalties. A recent study analyzing the effects of voluntary and presumptive guidelines in sentencing in Alabama suggests that they can have a positive effect on the overall lengths of sentences. $^{225}$ This study dissects the impact of such guidelines in detail, examining their effects on lengths of sentences and disparities between sentences imposed on offenders from different social groups. ${ }^{226}$ Overall, the study presents compelling evidence that the introduction of guidelines generally contributed to reductions in: lengths of prison sentences; disparities between sentences imposed on offenders from different social groups for similar offenses; and disparities in sentencing between different judges. ${ }^{227}$ While results varied between different categories of offenses, it appears that the introduction of voluntary guidelines reduced the average lengths of prison sentences by seven months, while presumptive guidelines reduced them by two years. ${ }^{228}$

While these reductions applied to both voluntary and presumptive guidelines, according to the raw data, presumptive guidelines seemed to have a greater impact. ${ }^{229}$ This impact was most pronounced among the middle quartile of judges in terms of how punitive they typically were, while the harshest and most lenient quartiles did not change much in response to the introduction of these guidelines. ${ }^{230}$ While voluntary and presumptive guidelines led to a significant reduction in the variations between sentences imposed on offenders from different racial groups where offenders were sentenced for drug offenses, they made almost no impact on the differences in sentences where such offenders were sentenced for property and non-worksheet offenses. ${ }^{231}$

This study's more sophisticated difference-in-difference model used additional variables, such as the type of court, in determining that presumptive guidelines had a significant and greater effect than voluntary guidelines on judges' behavior. ${ }^{232}$ Disparities in sentencing of offenders from different racial backgrounds also shrank under this model, but to a lesser extent. While disparities in the total sentences that offenders received for the same crimes decreased by about eight months, there was little impact on the lengths of prison terms that

225. See generally Griffin Edward et al., The Effects of Voluntary and Presumptive Sentencing Guidelines, 98 TEX. L. REV. (forthcoming 2020), https:/texaslawreview.org/wp-content/uploads/ 2019/11/Rushin.Printer.pdf [perma.cc/E59P-HQX6].

226. See id. at 29-33.

227. Id. at 33 .

228. Id. at 34 .

229. Id. at 33 .

230. See id. at 36-38. However, this changes between the types of offenses. When it came to personal property and burglary offenses, the inter-judge disparity seemed to decrease sharply as the harshest quartile of judges lowered their sentences to more closely mirror those from the most lenient quartile. $I d$. at 38 .

231. Id. at 39-40.

232. See id. at 41-47. 
were imposed. ${ }^{233}$ Across all models, the study purports to show that, while voluntary and presumptive guidelines effectively reduced the lengths of prison sentences, as well as disparities between judges' sentencing decisions and the sentences they imposed on offenders from different races, presumptive guidelines had a significantly greater impact in these respects. ${ }^{234}$

In suggesting that proportionate penalties are best achieved through introducing guideline penalties, it is also important to emphasize that prescriptive penalties are commonly criticized for the harshness of the penalties they prescribe, rather than for the mechanism they adopt for setting penalties. Proportionate mandatory penalties circumvent all of the flaws associated with many sentencing guideline systems that are currently operating in the United States, while maintaining all of the advantages of such an approach, namely, consistency, transparency and efficiency in the sentencing of offenders.

In the next section, we discuss how the sentencing system can be reformed to improve predictions of offenders' likelihood of recidivism. Prior to addressing this issue, it is necessary to flag the final key reform that we consider is necessary to ameliorate the mass incarceration crisis. To reduce the imposition of prison terms for the commission of a large number of offenses, such as drug, property and immigration offenses, it is necessary to provide for the possibility of imposing an alternative sanction for this cohort of offenders. An obvious option is probation. However, as discussed below, the rate of breaching probation is high and it is more prudent to develop a new sanction that, drawing on technological advances, can efficiently and effectively monitor the location and activities of offenders. The nature of this new sanction is discussed in Part III C below.

\section{B. Improving Predictions of Offenders' Risk of Recidivism}

Accurate predictions of offenders' risk of recidivism are critical to achieving the central sentencing objective of community protection, but also to the criminal justice system responding equitably to all offenders. ${ }^{235}$ The consequences of an inaccurate prediction can be dire for the offender who receives an unnecessarily harsh sanction or to the community if the offender, contrary to the prediction, reoffends. Given the importance of this assessment, it has for some time played a role in the criminal justice system. As Richard Berk and Jordan Hyatt note, "judges, as well as law enforcement and correctional personnel, have long used projections of relative and absolute risk to help inform their decisions", and "an increasing number of jurisdictions mandate the explicit consideration of risk at sentencing." ${ }^{236}$ At present, generally one of three methods is used to predict offenders' risk of reoffending, namely: unstructured assessments, which is the

233. See id. at $48-52$.

234. See id. at 58.

235. Id.

236. Richard Berk \& Jordan Hyatt, Machine Learning Forecasts of Risk to Inform Sentencing Decisions, 27 FED. SENT'G REP. 222, 223 (2015). 
method that is used most often; ${ }^{237}$ actuarial-based assessments; and risk and needs assessments. ${ }^{238}$ We now explain each of these methods and propose that, given their higher accuracy rate and greater potential for unbiased evaluations compared with the other methods discussed, risk and needs assessment tools be further developed and used more broadly.

Judges undertake unstructured assessments by considering factors relating to the individual offender, such as his or her criminal, education and employment history, as opposed to data concerning the variables and features that research has confirmed are generally relevant to offenders' risk of recidivism. ${ }^{239}$ The rate of accuracy of unstructured assessments is very low. ${ }^{240}$

As their name suggests, actuarial-based assessments, also known as "risk assessment tools," ${ }^{241}$ draw on actuarial evaluations ${ }^{242}$ of factors that have led to offenders' past criminality, such as their criminal associates and views of offending. ${ }^{243}$ The Post-Conviction Risk Assessment, used in the federal jurisdiction in probation matters, for example, takes into account the offender's previous employment and education. ${ }^{244}$ These tools then create "rules" about the likelihood of these factors to continue to influence the offenders. Studies have

237. Kevin R. Reitz, “Risk Discretion” at Sentencing, 30 FED. SENT'G REP. 68, 70 (2017).

238. As discussed further in this section, the main three methodologies are unstructured clinical assessments; actuarial methodologies; and structured professional judgment assessments. See Michael Davis \& James R. P. Ogloff, Key Considerations and Problems in Assessing Risk for Violence, in Psychology AND LAw: Bridging THE GAP 191, 195 (David Canter \& Rita Zukauskiene eds., 2008); Christopher Slobogin, Risk Assessment, in THE OXFORD HANDBOOK OF Sentencing And Corrections 196, 198-99 (Joan Petersilia \& Kevin R. Reitz eds., 2012).

239. Slobogin, supra note 238 , at 208.

240. Mirko Bagaric \& Theo Alexander, The Fallacy That is Incapacitation: An Argument for Limiting Imprisonment Only to Sex and Violent Offenders, 2 J. Commonwealth CRIM. L. 95 (2012).

241. See Pari McGarraugh, Up or Out: Why "Sufficiently Reliable” Statistical Risk Assessment Is Appropriate at Sentencing and Inappropriate at Parole, 97 MinN. L. REV. 1079, 1091 (2013).

242. See Melissa Hamilton, Back to the Future: The Influence of Criminal History on Risk Assessments, 20 BERKELEY J. CRIM. L. 76, 91-92 (2015); Michael Tonry, Legal and Ethical Issues in the Prediction of Recidivism, 26 FED. SENT'G REP. 167, 171 (2014). Such tools are in fact now used in the majority of states in the United States. See Shawn Bushway \& Jeffrey Smith, Sentencing Using Statistical Treatment Rules: What We Don't Know Can Hurt Us, 23 J. Quantitative CRIMINOLOGY 377, 378 (2007).

243. See McGarraugh, supra note 241, 1091-92.

244. Davis \& Ogloff, supra note 238, at 94 . Another common similar tool is the Level of Service instrument, which incorporates fifty-four considerations. See Slobogin, supra note 237, at 199. In terms of predicting future violence, it has been noted that dynamic measures are slightly more accurate than static measures for short- to medium-term predictions of violence. See Chi Meng Chu et al., The Short- to Medium-term Predictive Accuracy of Static and Dynamic Risk Assessment Measures in a Secure Forensic Hospital, 20 Assessment 230, 231 (2011). Given that these tools go beyond the use of static factors and incorporate dynamic factors, they are sometimes referred to as "structured professional judgment tools." Davis \& Ogloff, supra note 238, at 200. 
demonstrated that "the best models are usually able to predict recidivism with about seventy percent accuracy — provided it is completed by trained staff," 245 and predict offenders' risk of reoffending more accurately than unstructured assessments. ${ }^{246}$

Risk and needs assessments, which are used in decision-making about parole, ${ }^{247}$ probation, ${ }^{248}$ and, increasingly, sentencing, ${ }^{249}$ consider the treatment and rehabilitation required by the particular offender in order to reduce his or her likelihood of recidivism. ${ }^{250}$ The most commonly used risk and needs assessment tool is the Ohio Risk Assessment System, ${ }^{251}$ which takes into account factors including offenders' family circumstances, education and employment history, and any past substance abuse. ${ }^{252}$ Risk and needs assessment tools have a high rate of accuracy in predicting offenders' risk of recidivism. Nevertheless, concerns have been raised that their application can result in discrimination against certain offenders and particularly African Americans because, while race is not a consideration in these tools, ${ }^{253}$ criminal history is a consideration and more African Americans have prior convictions than white Americans. ${ }^{254}$ It is nonetheless possible to create algorithms for use by these tools that minimize the potential for bias to intrude into their assessments. ${ }^{255}$

For this to occur, it is important that the tools are transparent in that they acknowledge each of the factors that are used to predict an offender's risk of recidivism, and that they explicitly exclude any consideration of certain

245. Id.

246. Id.

247. Id. at 1,10 .

248. Pamela M. Casey, Roger K. Warren \& Jennifer K. Elek, Using Offender Risk and Needs Assessment Information at Sentencing: Guidance for Courts from a National Working Group, NAT'L CTR. FOR ST. CTS. 7, 16-17 (2011), https://cdm16501.contentdm.oclc.org/digital/collection/ criminal/id/196 [https://perma.cc/SDM8-EFHR].

249. Id. at 9, 13-15.

250. Kelly Hannah-Moffat, Actuarial Sentencing: An "Unsettled” Proposition, 30 Just. Q. 270, 276 (2013).

251. For an explanation of the manner in which it is used, see Superior Court Working Grp. on Sentencing Best Practices, Criminal Sentencing in the Superior Court: Best Practices for Individualized Evidence-Based Sentencing, Mass Superior Court, at viii (2016), https://www. mass.gov/doc/criminal-sentencing-in-the-superior-court-best-practices-for-individualized-evidencebased/download [https://perma.cc/F5UC-HN5Z].

252. Nathan James, Risk and Needs Assessment in the Criminal Justice System, FED'N AM. SCIENTISTS 2 (Oct. 13, 2015), https://www.fas.org/sgp/crs/misc/R44087.pdf [https://perma.cc/ XLY6-JBLK].

253. United States v. Taveras, 585 F. Supp. 2d 327, 336 (E.D.N.Y. 2008).

254. Mirko Bagaric, Three Things that a Baseline Study Shows Do Not Cause Indigenous Over-Imprisonment; Three Things that Might but Shouldn't and Three Reforms that Will Reduce Indigenous Over-Imprisonment, 32 HARV. J. ON RACIAL \& ETHNIC Just. 103, 105-06 (2016).

255. Jennifer Skeem \& Christopher T. Lowenkamp, Risk, Race, and Recidivism: Predictive Bias and Disparate Impact, 54 CRIMINOLOGY 680 (2016). 
immutable traits such as race, ${ }^{256}$ or at least "ensure that individuals are not treated differently on the basis of membership in a protected class." ${ }^{257}$ Monitoring, evaluating, and refining these tools can also help to remove any prejudice arising from their application. Notably, these tools have led to less disparity between sentences imposed for similar offenses on people of color and white people than unstructured assessments. ${ }^{258}$ (One study involving 77,000 offenders revealed that, where black and white offenders had similar criminal histories and committed similar crimes, the former received prison sentences that were 12 percent longer than the prison terms imposed on white offenders). ${ }^{259}$ Unstructured assessments also have greater potential than risk and needs assessment tools to discriminate against certain offenders because they inevitably allow judges' unconscious biases to intrude into sentencing. For instance, research has exposed that some sentencing decisions discriminate unfairly against offenders from economically and socially disadvantaged backgrounds. ${ }^{260}$

We therefore recommend that risk and needs assessment tools be further developed and implemented broadly in sentencing decision-making to determine offenders' risk of reoffending.

\section{Developing a New Sanction That Uses Technology to Monitor Offenders' Actions and Movements}

The third and final reform that we recommend should be made to the United States sentencing system also relates to the aim of community protection and to the acknowledgement that application of any methodology for predicting future offending will never be entirely accurate. It is necessary to put in place mechanisms to deter offenders effectively from reoffending and enhance investigative techniques so that offenders who do reoffend are more likely to be detected and prosecuted. It is clearly desirable that detection of their reoffending occurs as early as possible and preferably before or at least during commission of their crimes, so that furtherance of the offending is prevented, or its impact is

256. Crystal S. Yang \& Will Dobbie, Equal Protection Under Algorithms: A New Statistical and Legal Framework (Oct. 2019) (working paper) https://scholar.harvard.edu/cyang/ publications/equal-protection-under-algorithms-new-statistical-and-legal-framework [https://perma.cc/PDJ5-NCXM].

257. Id.

258. Rose Matsui Ochi, Racial Discrimination in Criminal Sentencing, 24 Judges J. 6, 8 (1985).

259. Ronald Everett \& Roger Wojtkiewicz, Difference, Disparity, and Race/Ethnic Bias in Federal Sentencing, 18 J. Quantitative Criminology 189, 198 (2002); David Abrams, Do Judges Vary in Their Treatment of Race?, 41 J. Legal Stud. 347, 350 (2012).

260. Offenders with more money received more favorable treatment from judges in cases involving child custody. Mirko Bagaric, Sentencing: From Vagueness To Arbitrariness: The Need to Abolish the Stain that is the Instinctive Synthesis, 38 U. N.S.W. L.J. 76, 106-07 (2015) [hereinafter Bagaric, From Vagueness]; Michele Benedetto Neitz, Socioeconomic Bias in the Judiciary, 61 Clev. ST. L. Rev. 137, 158-60 (2013). 
limited.

We also propose that the sentencing system move away from treating incarceration as the only effective form of community protection. This is especially important given that 95 percent of all offenders will be released at some point in time, and many will reoffend within a relatively short period of time, so any protective benefits from incarcerating them are merely transient. ${ }^{261}$ In fact, the recidivism rate of prisoners following their release is alarming. A 2018 report by the BJS on state prisoners released in 2014 showed that, of 401,288 state prisoners released in 2005, an "estimated $68 \%$ of released prisoners were arrested within 3 years, $79 \%$ within 6 years, and $83 \%$ within one year after release and not arrested again during the 9 years." ${ }^{262}$ These high rates of recidivism are also apparent in the federal jurisdiction. The United States Sentencing Commission recently reported on its findings from a study of 25,431 federal offenders who were released in $2005 .^{263}$ The recidivism rate amongst these offenders was measured over a follow-up period of eight years. ${ }^{264}$ When

261. The majority of the balance ( 5 percent) normally die while in prison. A small number are also executed. In fact, in 2016, there was the smallest number of executions (twenty) in the modern era (i.e., since 1976 when some states commenced re-enacting the death penalty). See The Death Penalty in 2016: Year End Report, DeAth Penalty Info. CTR. (2016), http://deathpenaltyinfo.org/ documents/2016YrEnd.pdf [https://perma.cc/Z7BK-P3TK]; see also James Gilligan, Punishment Fails. Rehabilitation Works, N.Y. TIMES (Dec. 19, 2012), http://www.nytimes.com/roomfordebate/ $2012 / 12 / 18 /$ prison-could-be-productive/punishment-fails-rehabilitation-works [https://perma.cc/Z9FZ-QDQR]. There are three reasons that prisoners do not get released. The most common is that they are sentenced to life imprisonment. There are, in fact, 160,000 inmates serving a life sentence and of these, approximately 49,000 have been sentenced to life without the possibility of parole. Life Goes On: The Historic Rise in Life Sentences in America, SEnTEncing PROJECT 1, 16 (2013), http://sentencingproject.org/wp-content/uploads/2015/12/Life-Goes-On.pdf [https://perma.cc/V8L4-NEVK]. Approximately 5,000 inmates die in state or local prisons and jails each year due to natural causes, illness or disease, suicide, or violence. See Margaret Noonan et al., Mortality in Local Jails and State Prisons, 2000-2013 - Statistical Tables, Bureau Just. StAT. (Aug. 2015), https://www.bjs.gov/content/pub/pdf/mljsp0013st.pdf [https://perma.cc/8WGMFZ3Q]. The number of deaths in federal prisons (444 in 2014) is reported in Margaret E. Noonan, Mortality in State Prisons, 2001-2014 - Statistical Tables, Bureau Just. Stat. (Dec. 2016), https:/www.bjs.gov/content/pub/pdf/msp0114st.pdf [https://perma.cc/77TR-HXTV].

262. Mariel Alper et al., 2018 Update on Prisoner Recidivism: A 9-Year Follow-up Period (2005-2014), Bureau Just. STAT. (May 2018), https://www.bjs.gov/content/pub/pdf/ 18upr9yfup0514.pdf [https://perma.cc/R79B-2E3N].

263. See generally U.S. Sentencing Comm'n, Recidivism Among Federal Violent OFFENDERS (Jan. 2019), https://www.ussc.gov/sites/default/files/pdf/research-and-publications/ research-publications/2019/20190124_Recidivism_Violence.pdf [https://perma.cc/NS36-FASX]. Among that pool, 15,427 offenders had no violent offenses in their instant arrest or criminal history. Id. at 2. Violent offenders are broken down into two categories: offenders who had been arrested for a violent crime (2,596 individuals) and offenders who were arrested for a non-violent crime but had a violent offense in their criminal history (7,408 individuals). Id.

264. Id. at 8 . 
compared with non-violent offenders, the study found that violent offenders reoffended at a higher rate, faster pace, and through the commission of more serious crimes over the eight-year study period. ${ }^{265}$ Violent offenders had higher rates of further arrest (63.8 percent versus 39.8 percent) and conviction (40.6 percent versus 23.3 percent), and return to incarceration (34.2 percent versus 18.5 percent). ${ }^{266}$ While the violent and non-violent offender cohorts differed from one another in their composition of individuals from different races and genders, both sets of individuals were virtually the same ages at sentencing (thirty-two and thirty-three years old, respectively), and release (thirty-six years old). ${ }^{267}$

Empirical data indicates that offenders' risk of recidivism is not substantially affected by the length of their sentences, regardless of whether they committed violent or non-violent crimes. ${ }^{268}$ Broken down by sentences of less than or equal to twenty-four months, twenty-four to fifty-nine months, sixty to 119 months, and more than or equal to 120 months, the recidivism rates of violent offenders varied by no more than six percentage points. ${ }^{269}$ The variation among non-violent offenders was even smaller. ${ }^{270}$ Nevertheless, individuals who were convicted for violent crimes as part of their instant offenses and received longer sentences had notably higher rates of recidivism. ${ }^{271}$

By contrast, the age of the offenders at release had a major impact on their rates of recidivism. ${ }^{272}$ Violent offenders released while under the age of thirty were more than twice as likely to reoffend as those who were released after they reached the age of fifty. ${ }^{273}$ The rate of reoffending amongst middle-aged violent

265. Id. at 3. Violent offenders had higher rates of rearrest (63.8 percent versus 39.8 percent), reconviction (40.6 percent versus 23.3 percent), and reincarceration (34.2 percent versus 18.5 percent). Id. at 11 .

266. Id. at 11 .

267. Id. at 8 . Black individuals made up 44 percent of the violent offender category, but just 27 percent of the non-violent offenders. By contrast, while whites made up only 38 percent of violent offenders, they represented 47 percent of the non-violent offenders. Hispanics were the smallest population in both sets, making up 12.5 percent and 21.2 percent of violent and nonviolent offenders respectively.

268. See id. at 15.

269. See id. Violent offenders recidivated at rates of 63.9 percent, 67 percent, 66.2 percent and 61.3 percent, respectively.

270. See id. Non-violent offenders recidivated at rates of 41.1 percent, 44 percent, 44.1 percent and 39.6 percent, respectively.

271. See id. at 25. Violent instant offenders recidivated at rates of 53.7, 60, 65 and 62.2 percent, respectively.

272. See id. at 16.

273. See id. While violent offenders released under age thirty hovered around 77 percent, those over fifty only recidivated at a rate of 36.4 percent. This trend was mostly the same among violent instant offenders, although each category had slightly lower percentage rates than the overall population of violent offenders. See id. at 26. Naturally, the trend was similar among only those who had violent prior offenses, but the percentages for each category were slightly higher than the general pool of violent offenders. See id. at 38 . 
offenders also varied considerably; it decreased from 67.5 percent for individuals between the ages of thirty-one and thirty-five to 60.4 percent for those between the ages of forty-one to fifty. ${ }^{274}$ The results for non-violent offenders are even more compelling. ${ }^{275}$ Individuals who were released when they were under the age of twenty-six were twice as likely to reoffend as their counterparts who were aged forty-one to fifty and four times as likely to reoffend as those who were released after they reached the age of fifty. ${ }^{276}$

Unsurprisingly, the recidivism rates for both violent and non-violent offenders varied also according to the extent of their criminal histories. ${ }^{277}$ Violent offenders reoffended at a steadily higher rate as their criminal histories grew more serious, but there was a slight decline between the second highest and highest classifications of violent offenses. ${ }^{278}$ The trend for non-violent offenders closely mirrored that of violent offenders, but the percentages in each category were lower. ${ }^{279}$ Notably, the recidivism rates of violent and non-violent offenders start to converge as they reach the higher levels of criminal histories, and the difference between each level starts to shrink. ${ }^{280}$ Nevertheless, violent offenders reoffend at higher rates in shorter periods of time when compared to non-violent offenders in virtually every category. ${ }^{281}$

Another recent wide-ranging survey of recidivism was undertaken in relation to offenders in California. ${ }^{282}$ The study focused on the effects of recidivism in the wake of California's far-reaching criminal justice reforms, which were introduced in 2011 in response to the United States Supreme Court's mandate to this state to reduce substantial overcrowding in its prison system. ${ }^{283}$ In addition, this study examined the effects of Proposition 47, a ballot initiative that reduced drug possession and lower-level property crimes to misdemeanors. ${ }^{284}$ The study followed 300,000 individuals released from either jail, prison, or probation,

274. Id. at 16 .

275. See id.

276. See id. Released individuals under age twenty-six recidivated at a rate of 61.9 percent, while the forty-one-to-fifty and over-fifty categories did so at rates of 29.8 percent and 15.2 percent, respectively.

277. See id. at 14.

278. See id. Violent offenders classified as CHC 1 (the least serious criminal history) recidivated at a rate of 44.5 percent. $I d$. This climbed to $60.1,67.3,77.2,80.1$ and 85.6 percent with each additional level of criminal history before dipping to 75.1 percent for the highest level_- "career offenders" and "armed career criminals." Id.

279. See id. At the lowest level, non-violent offenders recidivated at a rate of 30.7 percent, rising to $49.4,58.6,70.2,73.3$ and 81.8 percent before falling dramatically to just 50 percent for career offenders. $I d$.

280. See id.

281. See id. at 40.

282. See generally Mia Bird, et AL., Pub. Pol'y. Inst. of Cal., Recidivism of Felony OFFENDERS IN CALIFORNIA (2019).

283. Id. at 5 .

284. Id. 
across the counties from October 2011 to October 2015. ${ }^{285}$ Results varied significantly across sentencing groups in the wake of certain policy changes in California that affected specific types of sentences. ${ }^{286}$

Overall, there were declines in rates of recidivism in each of the sentencing groups; subsequent convictions dropped from $41 \%$ to $35 \%$, and felony convictions dropped from $30 \%$ to $22 \%{ }^{287}$ However, these results varied between cohorts of offenders. The rate of reoffending amongst offenders who had been sentenced to prison decreased generally, but there were more substantial declines in further arrests for felonies and subsequent convictions. ${ }^{288}$ Those released from jail saw fluctuations in rates of reoffending between 2011 and 2013 in each category, but then experienced significant declines consistently across all categories. ${ }^{289}$ Those sentenced only to probation saw a similar increase in rates of further convictions and arrests in the initial two years following the end of their probation, but have since seen substantial declines in both sectors. ${ }^{290}$

These results also varied according to the types of crimes that were committed. Convictions for crimes against persons decreased only slightly in felony reconviction, while the felony re-arrest rate actually increased by $7 \%$ over the same period. ${ }^{291}$ While re-arrest rates have also increased over time for property offenders, the overall reconviction rates declined in the latter two years of the study. ${ }^{292}$ Unsurprisingly, there have been the most substantial declines in reoffending where the offenders committed drug crimes, with reductions in rearrest and reconviction rates despite an initial increase to those rates in the first two years after $2011 .^{293}$

Prison can also be ineffective in achieving the sentencing goal of community protection due to its criminogenic impact. The experience of incarceration slightly increases offenders' likelihood of reoffending. ${ }^{294}$ Thus, it is vital that a new

285. Id. at 9 .

286. Id. at 10. For example, revisions to the "three strikes" law in California resulted in a sharp downturn of new people entering prison, and therefore the release numbers for that group dropped substantially.

287. Id. at 14 .

288. Id. at 18-19.

289. Id. at 20. Those sentenced to jail and subsequent probation saw similar declines in their reconviction rates, but have seen their re-arrest and felony re-arrest rates actually increase towards the end of the four-year period. Id. at 21.

290. Id. at 22 .

291. Id. at 15 .

292. Id. at 16.

293. Id. at 17. Notably, the rates of felony re-arrest and felony reconviction dropped dramatically in 2014 in the wake of Prop 47 going into effect.

294. Donald P. Green \& Daniel Winik, Using Random Judge Assignments to Estimate the Effects of Incarceration and Probation on Recidivism Among Drug Offenders, 48 CRIMINOLOGY 357, 383 (2010); Donald Ritchie, Sentencing Advisory Council, Sentencing Matters: Does Imprisonment Deter? A Review of the Evidence 22 (2011); Don Weatherburn ET AL., Criminology Research Council, The Specific Deterrent Effect Of Custodial Penalties 
sanction is developed that will better protect the public. In broad terms, the objective of the new sanction that we propose is to provide a means for courts to impose a punishment on offenders who have committed mid-level and minor offenses that does not involve them spending any time in prison. This new sanction could replace probation and ensure that all of the appropriate sentencing objectives for this cohort of offenders are achieved in a far more efficient and effective manner, while expanding the range of offenders who are kept out of prison. ${ }^{295}$

Our proposed sanction draws on technological advances that enable human behavior to be monitored closely and accurately in real time. Such developments are, for instance, currently applied in the creation of driverless cars and in hospitals to detect patients' falls. We recommend that they also be deployed to create a penalty that involves supervising and, where necessary, recording offenders' conduct for the term of this sanction. Sensor equipment can be developed to monitor offenders' locations and movements constantly. Technology that enables speech recognition and audio processing of emotional states could be used to determine if an offender is experiencing a psychotic episode or threatening someone, while GPS tracking could identify if the offender is attempting to leave a particular area. ${ }^{296}$ According to our proposal, if the technology detects any unusually rapid movement, which could occur if force is applied to someone or an object is picked up to be used as a weapon, it will trigger a camera to activate, recording the events. In addition, a corrections officer will be notified and an alarm will sound, alerting the offender and those nearby that the recording will commence. Such recording will not occur at other times, however, to protect the privacy of the offenders and those around them.

This sanction will undoubtedly achieve the sentencing objective of general deterrence. Would-be offenders are most deterred by the knowledge that their commission of a crime will be detected and punished. ${ }^{297}$ Offenders who are subject to this sanction will be conscious of the continuous monitoring of their behavior and location and, therefore, of the prospect that their commission of any crime will be detected, possibly even while they are committing it. They will also be discouraged from reoffending by their knowledge that the recording of their crimes can be used against them. Offenders will be aware that evidence of their commission of crimes that the sensors would not recognize as offending, such as online offenses, could nonetheless also be assembled by virtue of the constant monitoring of their conduct and location.

On Juvenile Reoffending 2 (2009); Franklin E. Zimring \& Gordon J. Hawkins, Deterrence: The Legal Threat in Crime Control 14 (1973); N.S.W. Law Reform Comm'N, Sentencing: REPORT 13933 (2014).

295. For a fuller discussion of the nature and use of probation, see Mirko Bagaric, Dan Hunter \& Colin Loberg, Introducing Disruptive Technology to Criminal Sanction: Punishment by Computer Monitoring to Enhance Sentencing Fairness and Efficiency, 84 BROOK. L. REV. 1227 (2019).

296. Id.

297. Id. 
Another advantage of this sanction is that it can be tailored to suit the type of offense that an offender has committed, and the offender's risk of reoffending. An offender who has committed a more serious offense might be prohibited from leaving his or her home, picking up items that have not been tagged, and engaging in any sharp movements. By contrast, an offender who has committed a more minor offense may be permitted to leave his or her home and pick up any items.

If, as we suggest, this sanction is used as an alternative both to probation and incarceration for offenders who have committed offenses other than sexual or violent crimes, we estimate that the prison population in the United States would diminish by around 40 percent. ${ }^{298}$ To lower prison numbers further, this sanction could also possibly be imposed on those offenders who have committed sexual or violent offenses, but are nonetheless found to have a low risk of reoffending and high likelihood of rehabilitation according to a risk and needs assessment.

\section{CONCLUSION}

The sentencing system in the United States is in a state of disarray. The United States has the highest incarceration rate in the world and there is no evidence that the community is reaping any benefits as a consequence. To the contrary, there is irrefutable evidence of the exorbitant fiscal cost of mass incarceration and its damage to many offenders and their families. Although there has been a reduction in prison numbers in the past few years, the decline is small and has been achieved through piecemeal reforms that lack a coherent and sustainable underlying philosophy or approach.

Only a considered, top-down, approach to sentencing reform can remedy the current crisis in the United States' sentencing system. In this Article, we have outlined such a solution and it involves three key reforms. The first concerns the manner in which sentencing determinations should be made. Abolishing mandatory or guideline sentencing would not reduce prison numbers significantly. Moreover, prescriptive sentencing practices are essential in order to ensure transparency, consistency, and fairness in sentencing. Mandatory sentencing grids have received considerable criticism, but only because the sanctions that they prescribe are generally too harsh. If the severity of those sanctions is moderated, the problems associated with mandatory sentencing will dissipate. Indeed, there is a sound doctrinal basis for reducing the hardship of most penalties, namely, the principle of proportionality.

Proportionality requires that there be a correlation between the seriousness of the offense and the hardship of the sanction. Empirical evidence establishes that serious sexual and violent offenses cause the most harm to victims' wellbeing. These offenses should, therefore, be punished through the imposition of

298. This is the number of prisoners that are in United States prisons and jails for non-violent or sexual offenses. See Wendy Sawyer \& Peter Wagner, Mass Incarceration: The Whole Pie 2019, PRISON POL'y INITIATIVE (June 28, 2020, 9:12 PM EDT), https://www.prisonpolicy.org/reports/ pie2019.html [https://perma.cc/3UVQ-WJ2W]. 
severe sanctions and, generally, prison terms in excess of five years. Research shows that people mostly recover more quickly from the effects of other forms of crime, such as property offenses. Consequently, we argue that current sentences for most property, drug, white collar, and immigration offenses should be significantly reduced, and offenders who commit such crimes should generally receive a sanction that does not involve incarceration. This reform would greatly reduce the prison population because, at present, nearly half of all prisoners in the United States are not incarcerated for sexual or violent offenses.

The second major reform that we propose is to develop further and use risk and needs assessment tools more broadly to predict offenders' risk of reoffending. We recommend that these tools use sophisticated algorithms that incorporate and calibrate integers that have been scientifically proven to predict accurately whether an offender will reoffend. Further, it is critical that these algorithms reduce the potential for application of the tools to discriminate against certain offenders. All of the factors that are used to predict offenders' risk of recidivism must be transparent, and the tools should be monitored, evaluated and refined where necessary.

The final reform that we recommend should be implemented concerns the type of sanction that is imposed generally where offenders have committed less serious offenses. We suggest the development of a new sanction as an alternative to prison, which embraces advances in technology, and effectively and efficiently achieves the sentencing aim of community protection, while ensuring that offenders experience deprivation that is equivalent to the harm caused by their conduct. This can be achieved by using sensor and surveillance technology to monitor and record the location and movements of offenders in real time. Such a sanction will cost substantially less than imprisonment. Moreover, this sanction will not have the criminogenic effect of incarceration, and its imposition could lower rates of reoffending.

The reforms recommended in this Article will make the sentencing system fairer, reduce its fiscal burden on taxpayers and increase community safety. There is no logical, jurisprudential or scientific basis for resisting our proposed reforms. It is hoped that any political opposition to them would be overcome by the compelling reasons in their favor. 